University of Louisville

ThinkIR: The University of Louisville's Institutional Repository

Electronic Theses and Dissertations

6-1949

\title{
I. Improved ice meltage in ice boxes; II. Temperature control in tents - winter phase.
}

Robert Beaman Duggan

University of Louisville

Follow this and additional works at: https://ir.library.louisville.edu/etd

Part of the Heat Transfer, Combustion Commons

\section{Recommended Citation}

Duggan, Robert Beaman, "I. Improved ice meltage in ice boxes; II. Temperature control in tents - winter phase." (1949). Electronic Theses and Dissertations. Paper 3067.

https://doi.org/10.18297/etd/3067

This Master's Thesis is brought to you for free and open access by ThinkIR: The University of Louisville's Institutional Repository. It has been accepted for inclusion in Electronic Theses and Dissertations by an authorized administrator of ThinkIR: The University of Louisville's Institutional Repository. This title appears here courtesy of the author, who has retained all other copyrights. For more information, please contact thinkir@louisville.edu. 
UNIVEFEITY OF LOUTSVILLE

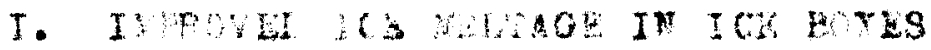

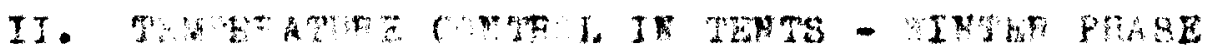

A Thes is

\author{
subritted to the Paculty \\ of the araduate school \\ of the Univoralty of Loulavizlo \\ in partial fulfillwont \\ of tho Roovirements \\ for the Degreo of
}

WATE OP Wh CA"ICHL WOTETSING

Iepartment of Hochanical sug inouring

Robort Bosman I ugban

June, 1849 


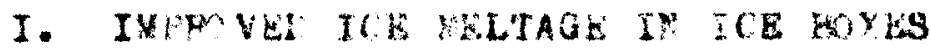

I1. TH

Pobert Fearan Iuggan

Approved by the wxamining committee.

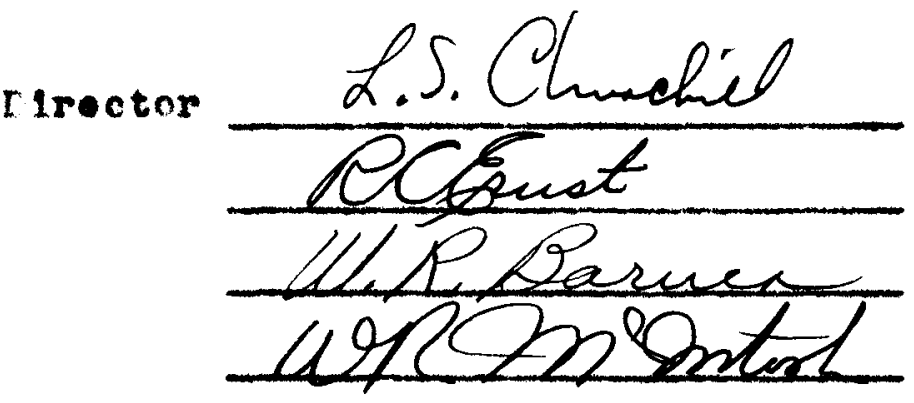

June, 1249 
ACRNOE 
The author winos to acknoviedse

the kind ase tance and helpful guidance

of Professor i. S. Churchi11

and Profeseor

who dirooted this research 
$\cos \mathrm{Luths}$

5

Acknowedgrert. . . . . . . . . . . . . .

Llat of tables...................

Liat of viguros ...................

Abstrect.

v111

I. Inproved too reltage in ice hoxes

Introduc tion. .................. 1

Theorotical ..................

Exporitronta1. . . . . . . . . . . . .

$y$

Conclualone . . . . . . . . . . . . . .

38

11. Teaperature control in ints - Inter thaso

Introduction. . . . . . . . . . . .

41

Theoretical ....................

Exporivental.

56

conelustone . . . . . . . . . . . . .

Literaturo Cltod.

79

Appendix. . . . . . . . . . . . . ...

BI

reknonlecgrent. . . . . . . . . . . . . ...

85

v tha

87 
Table I fenperature fronds in plrst 3 eries of

II Texperm tures of 100 ox in zourth serles of reat..................... 28

II Tempertures of ice ox in ifth sortes of ferte.................... 30

IV Terperaturea of Ice rox with original

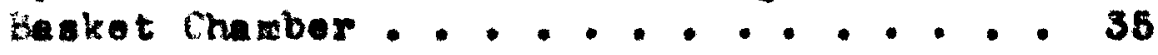

$v$ Temperatures of Ioe Box w th finsket-iuct Chamber. ................ . . 37

VI Loscription of pezperature veaurerenta. . 65

VII Surrery of Temperature Iata; Lare gall Font - No Liner............... 36

VIII Sumary of Temperature tata, large Tall Tent - two layer Liner........... 67

IX Sumrexy of Temperature LAta; Largo all Tont - Three Layer winer......... 69

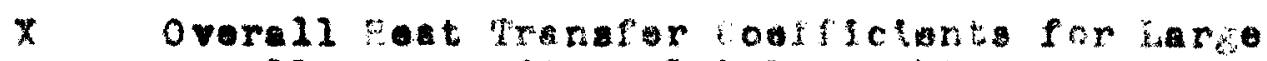
vall lant wir ult-layer Liner. . . 72

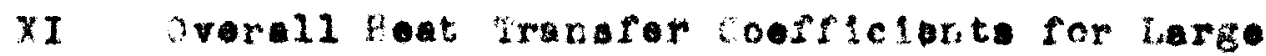

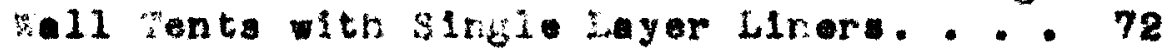

XI Lxperimontal ano inleulated Orarall feat Trenefer coefficiente........... 74 


\section{LIST OF PTOU}

8.

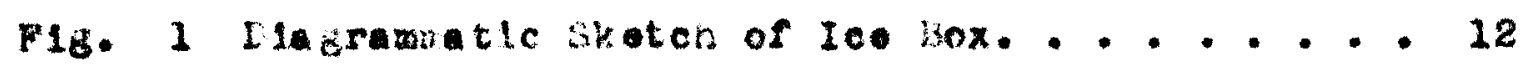

2 Sketch of Triblnal ce marber. . . . . . . 13

3 Therpocouple Locationo for rata of ablo I. . 16

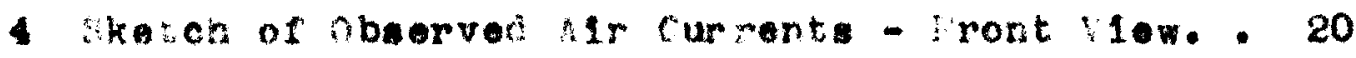

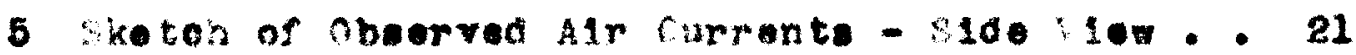

6 Sketch of Tovisod Ice thater arter swoke

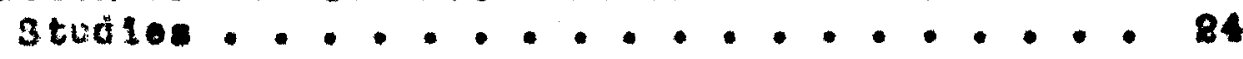

7 The mocouple Locetion for reta of Tables II and III....................... 26

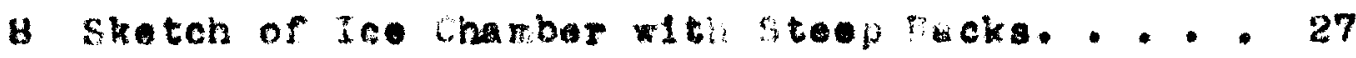

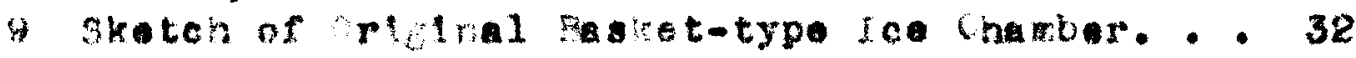

10 sketen of tasket-tyge 1ce Chanber with ict. . 34

11 Time-Terperature Delntione for Lare all perta without linera.................. 51

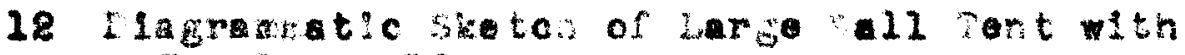

Two Lager IIner... . . . . . . . . . 59

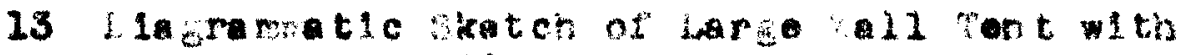
Trres Layer Liner... . . . . . . . . 6u

14 Lecation of lenperature esaurentant. . . . 63

16 Le ta shet for soullibrlux conditiono... . . 64

26 Uround rexpere ture tarlation tenter of Tont. 71 
AESTFACT 
Th1 thoa1s consits of two partes Improved Ioe

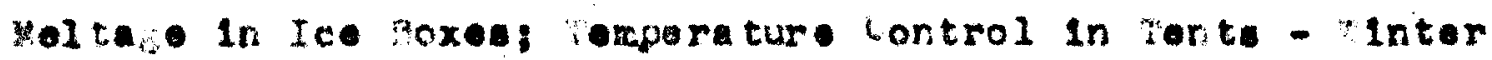
thase

Improvec lce meltage in the progreas rofrgerator 1. alscusaed in the first jart of the thools. Ins portion

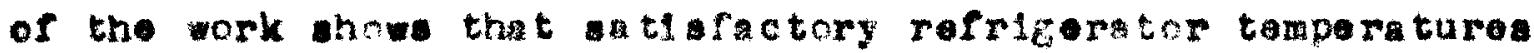

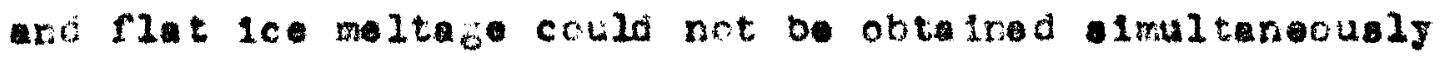
when ualng l-ahaped lee racks, al though they could be obtalned seperately; howerer, the baket-type chamber of fere

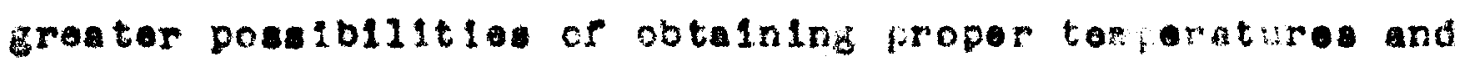
rol tate charactorletica. Sorios of teats aro d lscused and concluelons dram frow the railite.

In the second part of the thesia a wethod of treeting data obtained in the trenefer of noat into ano froe 11:tary tenta wa developed and applied to the oxporitrontal data. A atudy wa rade of 1 arge wall tonta, using as insulators the following types of linara: 3.6 oz. cotton, 2 layers of cloth; 4 oz. cotton, 2 layera of cloth, lnat fabric - dark green, Inyl-coated; 40. cotton, wita, 3 Iagers of cloth. Heasurents were made of tont alr and fabric terpera tures urder conetent hest input condltione, and orerall heat tranafor cofficlonts wero calculated for comparioon of the lnsuleting vallea of the linera. 
PART L I HPOVIS SOE BELTACE IN ICE BOYES INTPTECTLN 


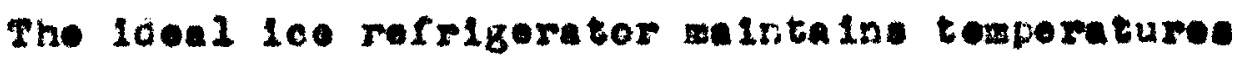
at level requlsed for proper food preeervatinn, wile offerIng econory and convenience of operation. Each of these factors is of sufficient importance to warent serious oonalderation in the design of loe refrigeration oquipment. Tomperaturea in the refriberator not only aut be at aufleientig low level. in the neighborhood of $40^{\circ} \%$ but wut show 11ttle veriation within the rood compartment. A difference of more than ten degrees between the maximum and anlaus temperatures in the 100 chaber is not doslrable. Purthermore, tomperatures in the food compartment mut ranain subatantialig constant after the lee block hes melted to approximtely $20 \%$ of it orlgini alze. Unoue variationa of comperare realt ing frow reductions in the size of the lce block oan cause roou epollage.

Ease of cleaning, nbeence of dripplnge and weana for convenient arrangesent of food within the chamber are the features reculred by the oner. Thea conelieratione dictate a imple arrargenent, particulariy of the lce chaber. to pormit easy asembly and dieasembly for olenplng. The de- len must be such as to channel all dripping from welted lce or frow condened woleture into arain plpe. Any dripping Into the food compartment 1 ariou faliure of the rofrigerator. In designing for conventent arrangement of rocd, 1t 1. most important that provision be made for atorage of w1k bottles in the coldeet part of the food compartinent. 
M1k bottles are bulky objecte and their errargewent on atandard ahelving in cold pot often preents diffleult problems. Equally 1mportant re the foaturea requirod for the convenlence of the "leoman" who servioes the refrlgerator. A refrigerstor is neaded into which atendard alzo block of lce can be placed at toride interval. whout roguiring any othor attention. This objective has not been atialued in any commerchl refrigerator now on the market. Ueually, the Ico-man 1. rocuired to ke room for now 1ce by chlpping away the remalns of old blocke. Because of this or other undealrable foetures, he mag be forced to set his lee lond on the floor of a kitchen wile ho worka on the refrigorator, procodure that houserives rind objectsonablo. Sultable provision for oasy relcing was the jor proules encountered in the rork covered by this problem of the thesis.

Aleo, oconomic conslderationa rocul to the rerrligerator to do low in first cost and lce consumption. These consiceratione must obviously be met if tho refrigerstor la to e.11 competitively. 
PEEORETICAL 
Under conditions of thersel equilibrlum the temperatures that are antelnod in the refrligerator aro such as to balance the rlow of heet through the ineulated walls of the rerrigerator gainet the hout transfor betwoer air and ico in the refrigoretorl angthing that tonds to incrosse the beat flov through the mils corrospondingly incroases the tempersturos in the rofricorator. similarly, anything that docreases the rate of hout transfor from $1 \mathrm{r}$ to ice incriases the tempera turea.

Iurlng the investigation covered by thle thesis, nothing wes done to effect the rate of hat flow lnto the box. Th1s rate 18 dotereined elmost ontirely bj the ambient tomporature outalde the box, the thermal conductivity of the rofrigerator walle, and tho oulliorlum tomper ture in lide tho box. None of these could be conelderod en independent var1able for the purpose of th1s investigation. In all teats of a ouant1tative nature, tho outside ambient was hold constent at a opolfied tempernture of $88^{\circ} \mathrm{F}$. Also, no change was mos in the Insulating propertios of the walls. Therufore, any change in the rate of heat flow into the box was caused by a correspondirs change of conditi ons ing loe the refritoretor.

Thus, the rate of heat tranofer between 100 and alr Inside the refrigerator is the greateat single factor daterming the tempereturo lovel at equilibrium and dopends on four varlable quant 1t1es, all of whloh are important: 
1. The differonce in twopereture botwer the a $1 \mathrm{r}$ and the 100 ith injob it is in contact. Inabuoh as the 100

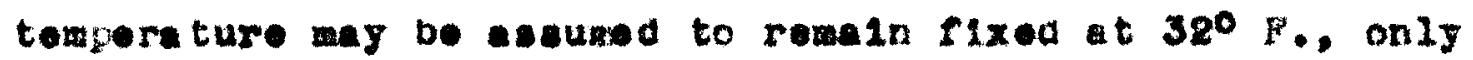
varletione in ar tomperature need bo considerod. The rate of het tranafor w11 way jroportionally with this tomporature difrerence.

2. The aroo of cenect betweon the lee surface and the alr. The 2a rger this aree, the highos In the rate of heat tranefer obta 1 ned.

3. The rasictance to hest flow botwean the 100 end the air. Inla roelatance is dependent in large neesure on the velooty of the efr flowing pat the lce. At low alr velocitian. layer of ar tonda to cing to the tce surace, - frectively insulating it from the buik of tho adjacent warror 1r. ks tha velocity or the ar pat the 1ce 18 Increasec,

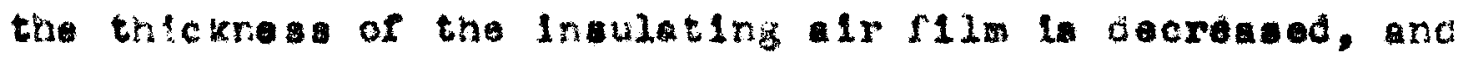
hoat truser is 1 mprevad.

4. The amount of extended heat tranafor surface present. Son heat tranefor can take plice between alr and wetal firs. the flue tranaferrint heat to the 1ce. ithin reasonabio 11mita, this exterdoc arface y be regarded a -quivalent to daitional 100 area.

Decause of the importance of ench of tha above

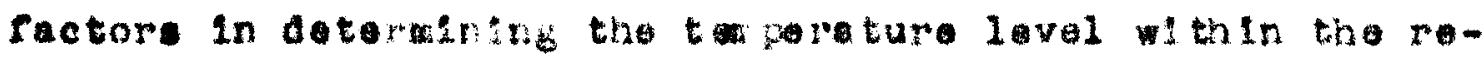
rrigerotor, eh rust recelve consideration in dosign. 
The question of temperature difrerence, while oubject to only very Iinited control, werits considerable atcention. One of the not aseficult probleat encountered in th1 a noric was oblectlonably sow lee meltinis at the center of the 1o chamber where the tam rature difference is lowet. The questions of lce area and extended surface erea cannot bo neglected. Who conventional dosigr of 1 ce racks provides a nutber of horizortal fins on which the lco lo apportad. In operation, this type of rack cauber the bottom aurfaee of the 100 to welt into a number of V-ahaped groover. exposing wuoh wore ares to the alr etrean than would be the oase If the ice aurface were flat. Hloo, the fins act as oxtended surface glvine additional beat trarafer aroa.

of the factors wentioned, realatanco to jeat transfor 1 s tho act cricical because it is aubject to the groatest relative variationas a result of concitions within the refrlgeretor. Aa ha been montioned, resistance is determined almot ontiroly by the velocity of the clrculating air rlowIng pat the sce surfece. Because of the protical importance of thermal circulation in deteraining rates of heat transfer, detalled consideration w11l be alvon to thla phenowenon and to tha factors thet control the rato of thermal circulation.

In the refrigerator of conventional design, eir tends to rise at the wallo bocause it is wamed by boat conductod into the refrigerator. Aftar pasing over tho lce block 
ard belrg cooled, alr descende et the center of the refrigerator. The following two varlablos control the rute at wioh this thermal circulation takes place.

1. Fhermal head. This is the presare diferontial that would exlat if a colum of relatively wam alr adjacont to the walla of the refrigerator could be held atationary in conjunction wth cold column of alr at the center. The megnitude of the thermal bead depends on the helght of the two colume and the difference in temperature between then.

2. Plow resistance. Flow rositance reoults from obatruction placed in the path or the clreulating alr. It 1. caused by aharp bende in the tlow fath, reatelcted rlow paseages, and suddon changes in cross-iection of the flow pasange. Wlow realstarce causes lose of prosare in the rlowIne 11quid, the exnct ma gn tude of the ereseure arop dependIng also on the veloelty of rlow. An lncrease in elther rosictarce or velocity causes an increase in prosure drop. When tempera ture differentials sot up thermal hoad and air atarta to clrculato, the rato of elrculation increasea unt the preseure $20 s a c e$ caused by flow resiatance balance the preseure differential due to the therwal head.

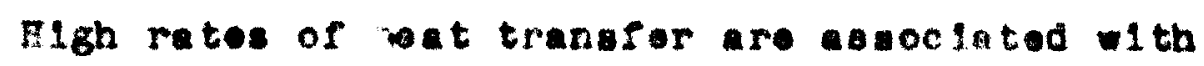
high rates of thermal circuletion. ing change that docreases the flow resietarce in the ciroulation the or increases tho helght of the olrculation path. will improve circulation and heat tranafor and roaul in lower refricerator tomeraturea. 
EX PSP I ENT AL 
A eketoh of the original proerese rofrigerstor is whom in plgure 1. It bas a alx cuble foot sood corpartmont with an ice chamber doalgned for 100 -pound block of lce. This rofrigerator bes an inulated couble wall construction,

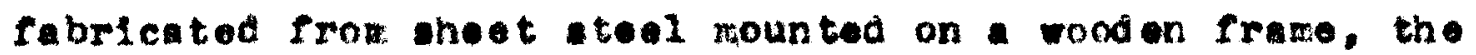
spece between the walls belne r1110d with blankot blass-mool. Tho Inalde nd outalde aurfacos core colth white baked onamel finlah.

The 100 ohaber, shom in tiguro 2, 10 largo onough to nocomodate atanderd 100-pound block of 100 wth enough additional spee for approximetely thirty pound of leo that way remaln from previous leings. Constructed of sheet steel

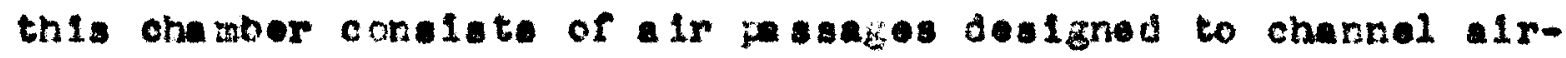
110 paot the 10e block, rack to oupport the ice in It propor position, ano traje to provent condensod moloture ano lce wel tege frot dripping into the food compartment.

Two difforent typos of teats woro carried out to Investigate the performanee of varl ou $100-c h a m b e r$ designs. one wa both quantitetive ad quelitutive in nature, giving quantitetive information on the texperetures attalned in the refrigeretor and on the rate of 100 tage, wh1le also giving qeilative inforeati on on the Ir circulation pathe through the refrigorator and on the characteristics of lee moltage as revealed by the shape of the ice block. The socond test wa ontirely qualitative, bolng an investigation of the circulat on patis through the rofrigerator as rovealed by smoke 
injected into the intericr. Eereaftor, those tosts will be roforred to as "temperature teate" and "emoke toets" roupeotively.

\section{TEMPQTEURE TESTS}

An external abblont close to $88^{\circ} \mathrm{F}$. we malntelnod during all tomperature teats. To meintilo this abiont, the refrigerator was kegt in a beated room, tho temporature being

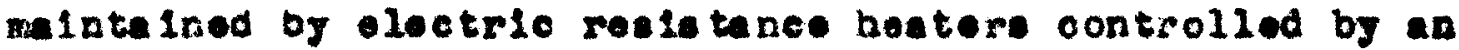

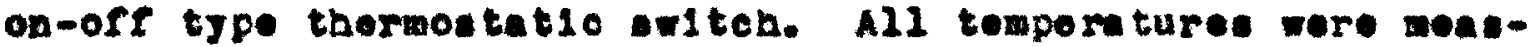
urod by copper-cons tanten thermocouples usod in conjunction with a poteptlometer callorated alrectly in degrees fahrenholt ane having an atomatie cold Junction compensation. The only other equipment neoded wae means of collecting end volghing alted ice from the refrigerator. For this purpose contalnor was placed under tho drain, and platform sceles wore used.

In all temporeture toste a run was aterted by placing a 200-pound blook of 100 in the chamber. Standard blocke as perfectly obaped as posalble wero used, 1.0., blooke uf th in extrem taper or a 1thout equare corners were avolded. After the box had reached equllibrlum, the tomperatures were recorded at regular intervale. Nater from melted 100 was romored porlodieally, Ito wolght and colloction time reoorded, and rate of meltage conputed. 


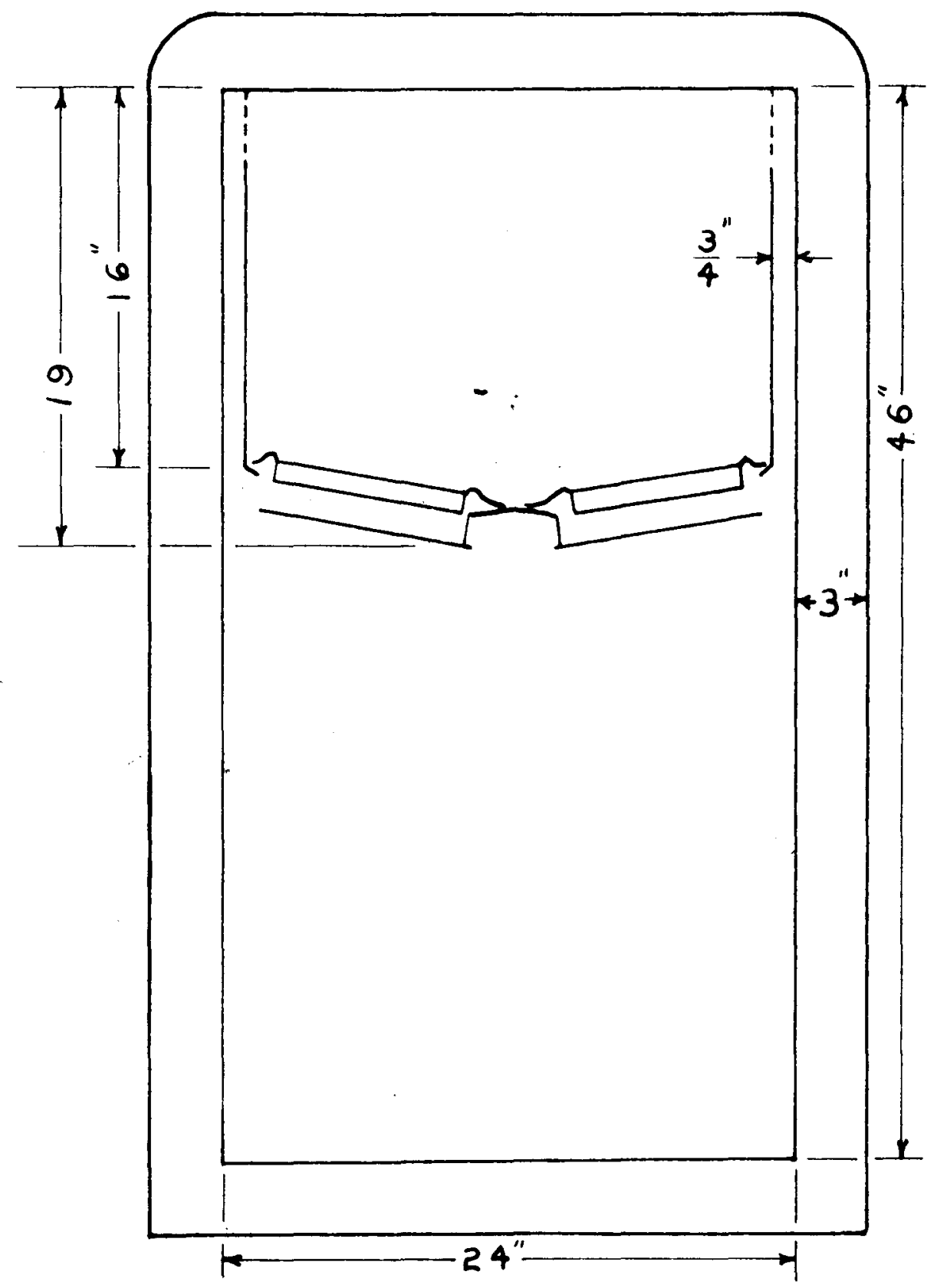

FIGURE I DIAGRAMMATIC SKETCH OF ICE BOX 


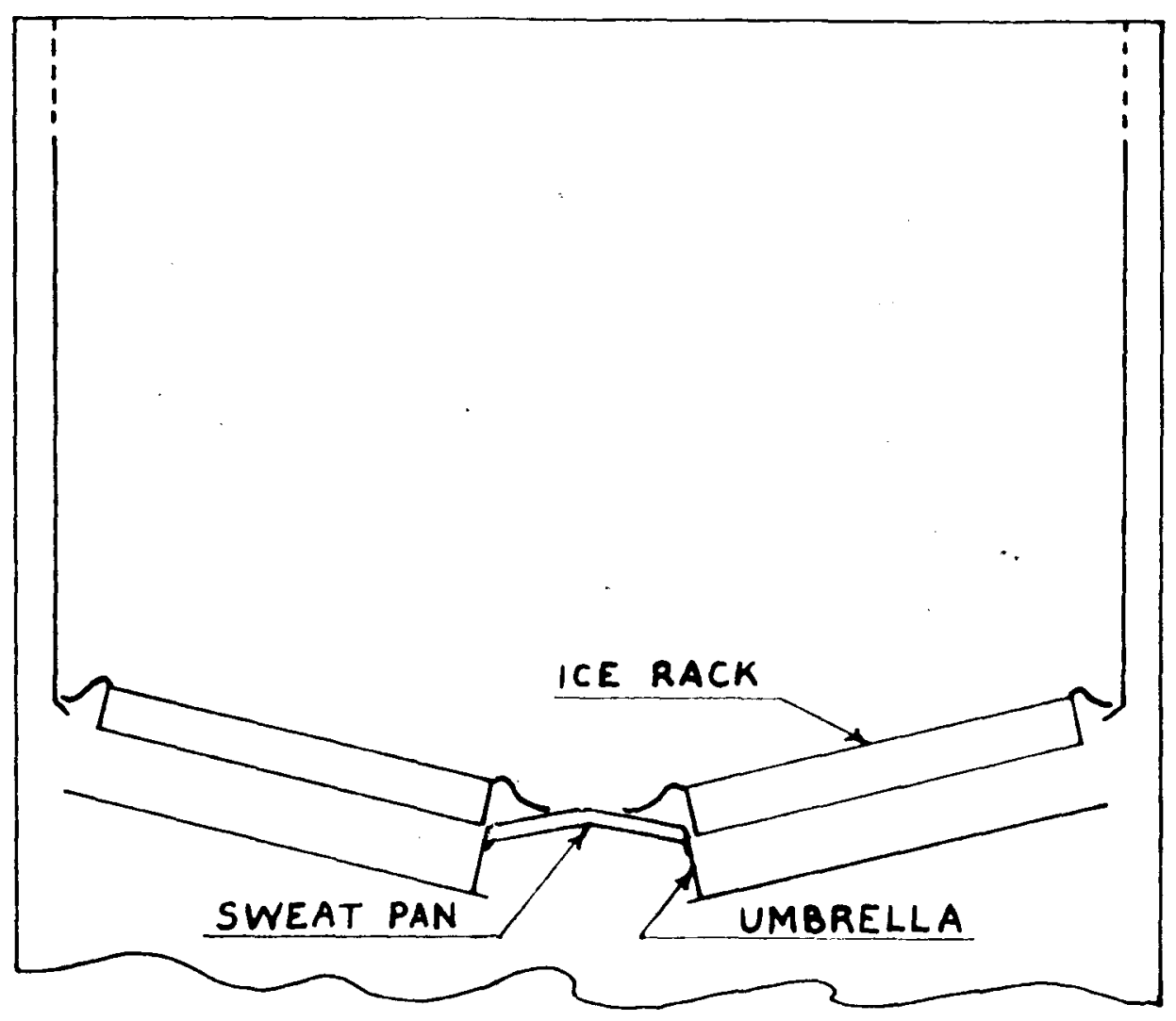

FIGURE 2 SKETCH OF ORIGINAL ICE CHAMBER

$\bar{\omega}$ 
SHOK: TESTS

Tho principal problem in the swoke test wa making the alr currents in the refrigerator ouffleiontly visible for observation. To attaln this objoctive, a doneo, porsiotont moke was requ1red whlch was non-corrosive and could bo produced at a low temperature. Th1s latter roculroment ruled out all smokes produced by combuation proosases. After a perlod of trial and error, amonlum obloride amoke was adepted for the experiments because, in addition to weting all the above-mentloned renulromenta, it wa eas to generato. The smoke was generatod outside tho rofrigerator and infected into the alr strean through aole in the wall of the refrlgerator. To make the smoke read1ly vialble, a weter-o0luble black palnt was used to cont the interlor of the refrleorator. For convenience in obeerving the ir streas, tho Invulated door of the rofrigerator and the bopper front were roplaced of sheots of plate glass, seled at the edges with masking tape. Beceuse inallating propertios of this glase panel wore quite different from those of the or 1 blual door, the ambient temperature was malntelned at a higher value outald of the Insulsted refrigerator walls than outalde of the 8lase. To insure appoximately uniform hoat conduction through all panols, the external amblents wero adjustod to g1ve aurface tomperature or the insioe of the glasa sub-tantially the saxe sthet on the inelo of the insulated malla. 
A 100-pound atmeciard llock of lae was placod in the 1ce charbor, the elexe door ano hopper front were pleced In position and sealud, and the refrigeretor wall allowed to reach equllibrium. The external ambiont on the insulated walle was thon ojuated, ano tho rafrigerater was givan time to raach therow aquilibrium conditiona. Aftor the refricarator talned an onulifbrium conition, the moke was ingected Into the box. Sketches wore sade showng the ir current. observod. See plgures and $b$.

For the sake of convenionce the reault of 1nd1vidual teats are grouped in sovoral corlosi the da ta obtalned In oach sories and tholr interprotation ara prosented soparately.

Piret series

The puxpose of this sorlee was to ohock the performance of the production undel of the Progrees refrigerator. A tempere ture test was carried out and the data given in rable I wore obtalined. Texperaturea were wesured at the polnte ind loated in Pigure 3 .

As can be seen frox. Table I, the tomperatures attalnod in the refrigera tor wore good, lnd leating adeouate thermal olrculation and heat trensfor. No mater was observed to drop into the food comproment. Howevor, the characterietics of the Ice weltage were completely unatisfactory. The 


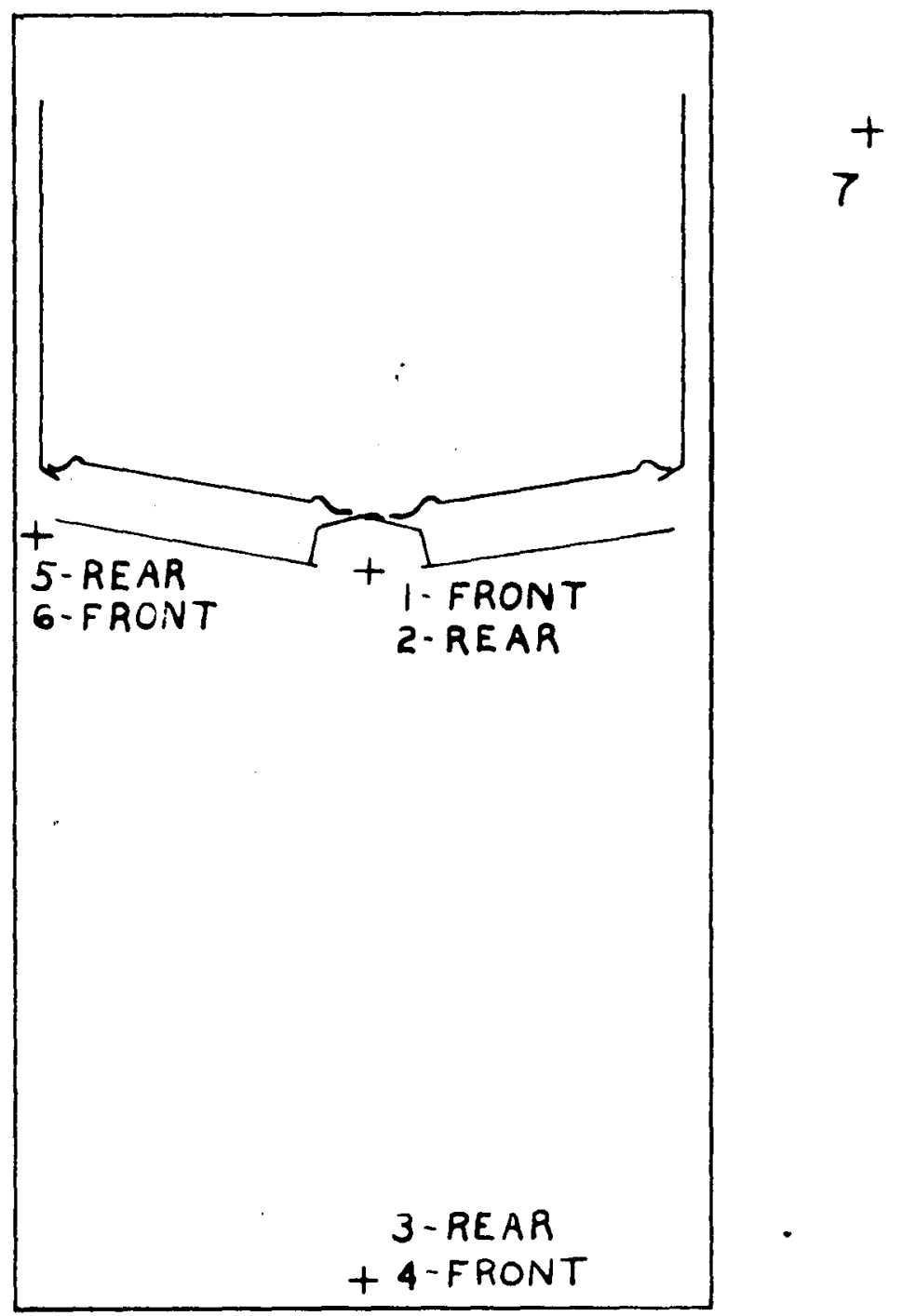

FIGURE 3 THERMOCOUPLE LOCATIONS FOR DATA OF TABLE I 
TABLE I

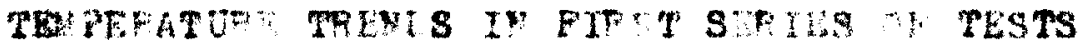

Therwocouplo

vumber a

Show in

Heare 3

1

2

$\mathbf{3}$

4

6

6

7

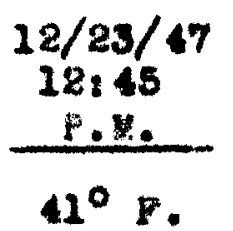

10

49

49

82

82

88

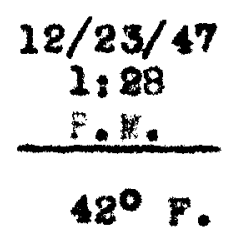

41

50

60

86

64

90

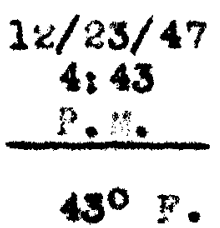

42

58

52

67

86

99
$12 / 24 / 47$ 3: 52

B. Z.

$42^{\circ} \mathrm{F}$.

41

62

82

B8

86

89 
1ce tended to welt Into rounded mound, which wa objectionablo bocause it did not present arface at the time of releing on wich nes blook of lce could be etabis aupported. purthermore, the blook anowed covere underouttine at the back and sides, aurficiont in itsolf to cause tatio inatability. After releing, the orlginal block romalned unmelted for a long porlod of tine at the center of the 100 chamber, Ind1cating tonofoncy for 1ce to accumulate at that point and ade to the Irconvenience of rolcing.

In N1gure 2 a dead a ir epeee onel osed botween the top of the umbrella and the seat pan loceted Imaediately below it is shown. The purpose of this aweat pan was to prevent the dripping of condensed moleture into the food compartmont. It was thought thet the insulating properties of this dend-eir apace had mach to do with the objectlonable meltage charactoristica obaervod. In the second serios of tests erforts worn do to correct this condition.

Socond serten

Tho sweat pan wes remored, and a socond terpereture test was carried out. The tompera bure deta recordod during tho tast woro unchaniged. Moltage che retorlstics woro only alightly 1mproved, if at all. Tho ice continued to molt into - rounded mound and to ccumilate the center of the 100 
onamber above the unbrella. The oxplanation for this nezilglble Improvement was that as the deacendine alr atroems left the underside of the lce and turned domwerd into the dow draft, there wes not suffiolent contact with the bottox of the unorella.

A third serios of tost wa undertaken to undoratad wore fully the a curronts in the refriforator.

\section{Third serlee}

All the toats in this sories wore soke tonte and a such ylelded only qualitetive informtion. Because the purpose of the teats wa to investigate alr current in tho -tandard production model lee chabor, tho rogular loe chamber was used wth standard 100-pound blocks of 100.

The jor air curronte obeerved in tho refrigerator wore as shown in Figure and Flgure 6 . An yp-druft was observed at the siden of the leo ohmmber, the major part of wich a acended to the top of the refrigerator, with comperatively amall ount ontering the lce chamber below the 10e level. A wuch atroager up-draft wa found the front of the refrigerator between the door and 100 chamber front, the velocitios in thle strear telng several times those at the side. At the top of the refrlyerator the three streame from the front and oldes werge and desent slowly over the 1ce block. The flow over the surface of the block wa thin, 


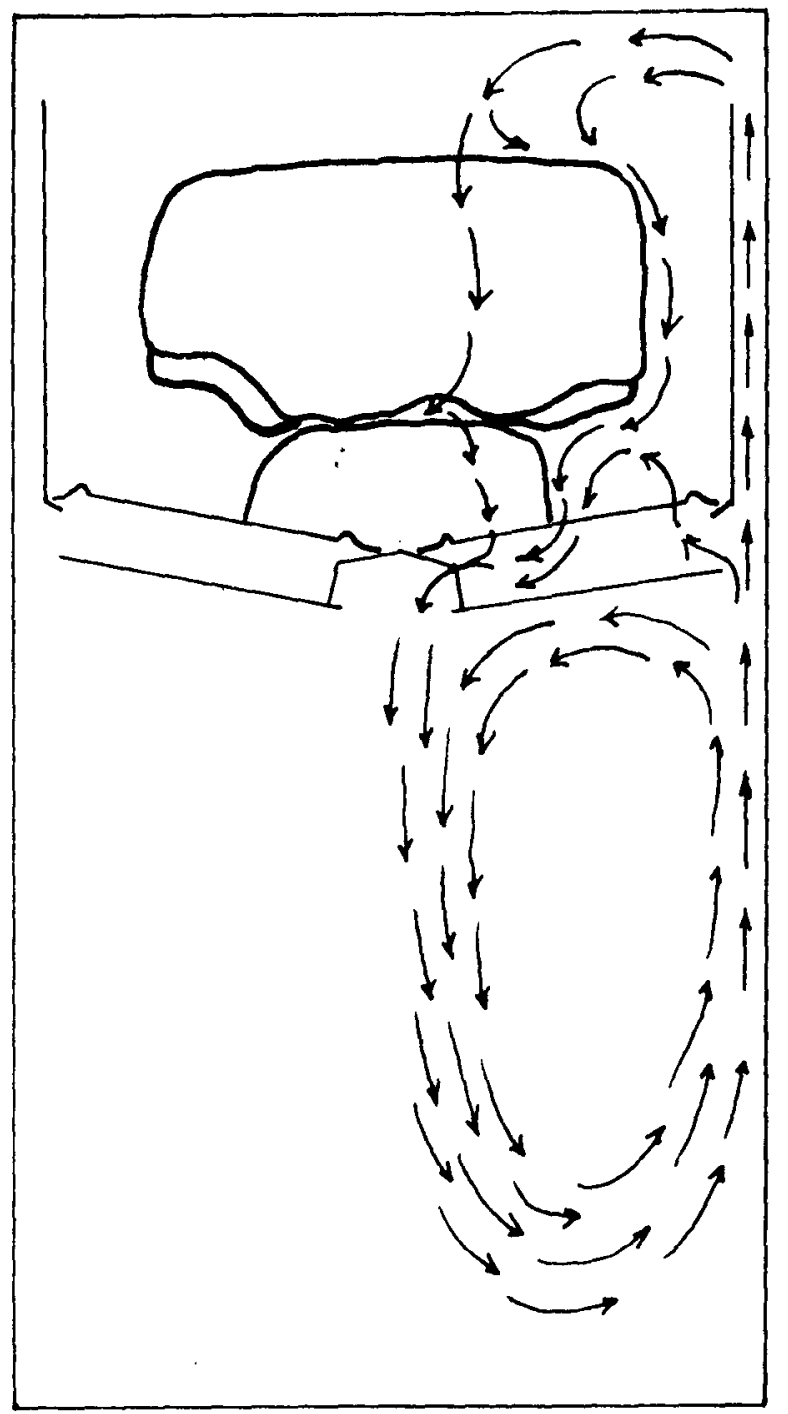

FIGURE 4 SKETCH OF OBSERVED AIR CURRENTS - FRONT VIEW 


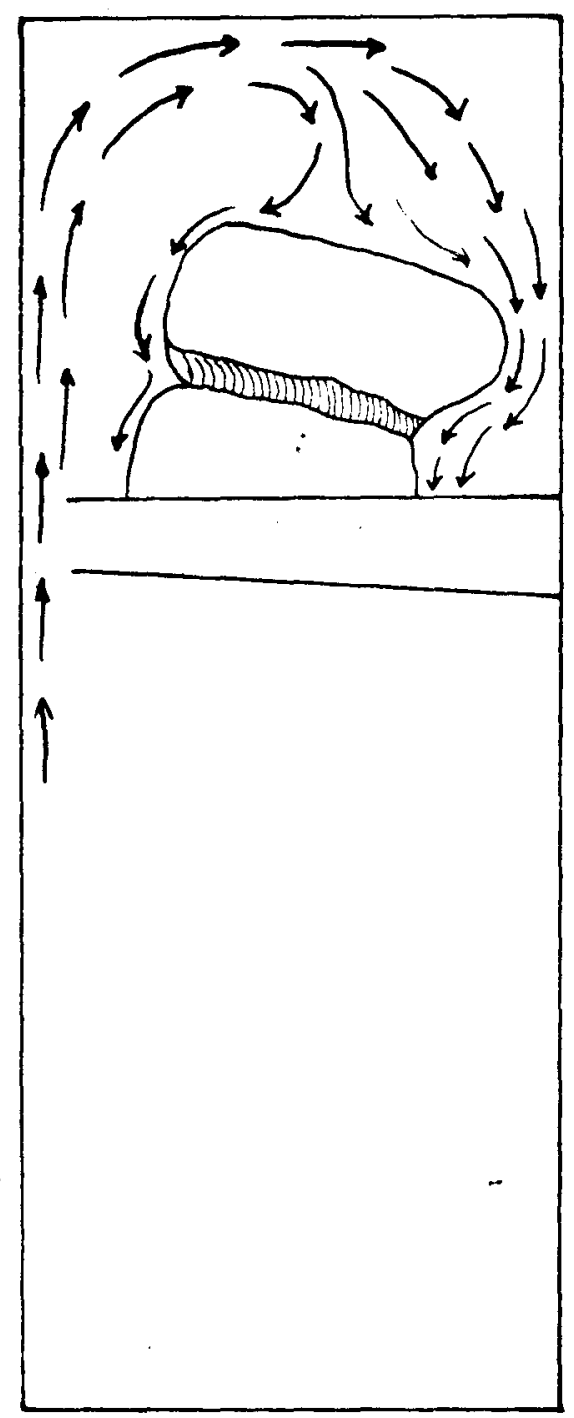

FIGURE 5 SKETCH OF OBSERVED AIR CURRENTS SIDE VIEW 
clinglng 113 on the 1es aurface, with the groetest part or the flow occurrine at the beck of the block.

ralle ondy a mall orcentage of the total clrcuIating air ortered the 10 cherber the lo to below the 100 rack, 1t wa rourd thet th: otres caluod tho undoreuting observed at the sldos of the leo block. As the streac ontered the ice chamber, It tended to rise in the sace botwoen the slet of the lce block and the alde well of the lae chamber. In rialne, 1t care in contact with tho loo, who cooled, and

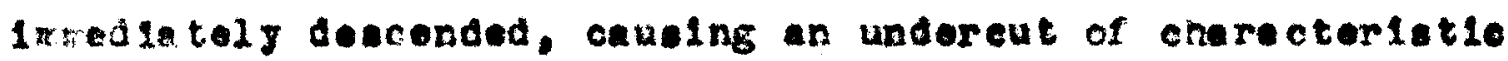
atape.

The undercutting at the back of the 100 block was found to be caused by the alr atroam riglng the frent of the refrterator. As indicated in Figure 5 , the kinetio oneray of this etrear is auffeiont to carry it to the rear of tho rofrlecrator fter it ronohe the top of the ice chamber and turns townd the oonter. The highost veloeitios observod in the rofrigator wore the down-draft in the center of the lce chamber whero all the ir atren morged. Frow those awoke studies it was apparent thet a flet ice surface could be obtained if beat trancfer were reetrleted to the botton urface of the blook. To obtein this condition the following modifientions in the original dosign ware mades

1. A gasket wae placed botwenn the aoor of the refrigerator and the ice chamber. The purpose of the ganket 
was to prevent circulation of eir from the fooc coupretiont to the lee chanber at the front of the rofriferstor. 2. Quide varea were piscod in the alr otrowat tho side of the ice chenoer to cirect this etranin lue er tho ice anc furtior prevent circulation to the top of tho rerricerator.

3. Tistos were is sterod to the ice racis at tho sldes to provent undereutting. ghose platea wore folded so thet thoy wi ght arvo as guldos for the loo block.

4. Tho unbrelle wa ontlrely romoved, and the 1co racks auported at wach ono.

5. A Orlp catch was Installod benenth the dowdraft opening.

Figure 6 shows the ice chember incorporating these changes. A fourth oerles of teats was de uling this ico chanber.

Yourth sorles

Voling this wodifl od ice chabor, smoke test was mode. All circulation in the upward olrection was through the leo chamber inlot. nt the sides below the leo racks, townard clrculation wa till confinod to tho dom-draft opening at the center of the refrigeretor. The efr valocity at this point we found to be boon docreaed subatantiaziy. 


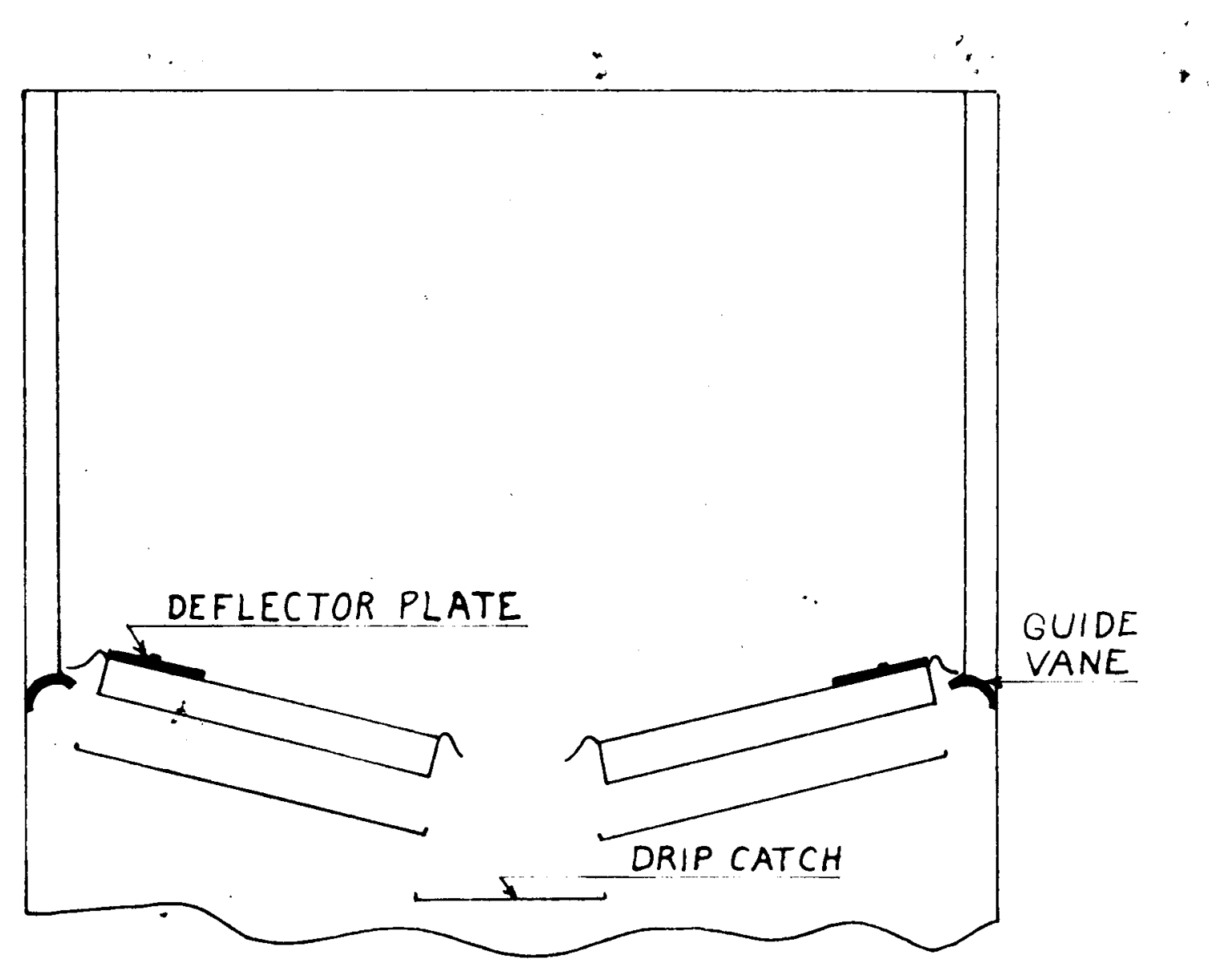

\section{FIGURE 6 SKETCH OF REVISED ICE CHAMBER AFTER SMOKE STUDIES}




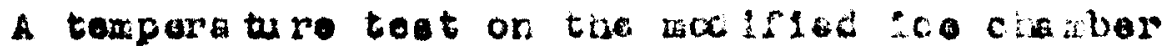
was carrioo out noxt. Unetiafactorily bigh tonpere turos

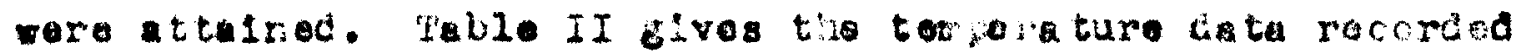
for tro tost. The therrocouplo positions for tis s tablo are

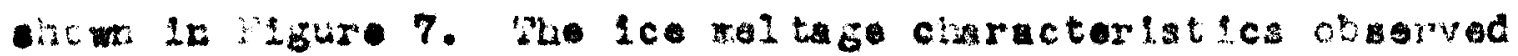
ourlne the toet vere atisactory, havover. The inttial block of lce matre inod liat upper surface wile weluing.

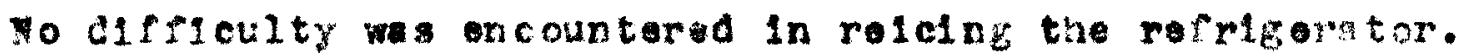

mao noxt atop was to lower the rafrig tor temperaturea to the destred lovel without asorifleing these moltage cheractoristica. It wa docidod to lncrease the eflective themal hand in the rofregorato by inereasive the alope of the 100 racks. This change ralad the ar inlet

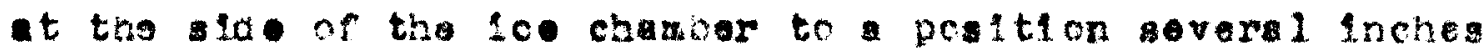
obove its orlolaal location. Aa result, the helght of the orfoctive ir column in the refrigerator wa increased.

Plgure 8 is aketeh of the fo chamber bul1t on this prinelple. The 1ce chamber was installse in tho reIricoretor. and fifth eries of teats wa carriod out to check its porformance.

\section{Pleth series}

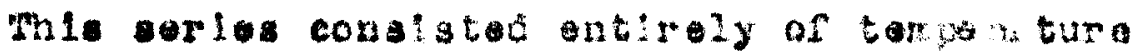

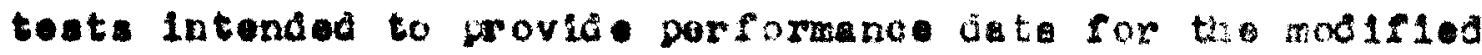
1ce chember with toop lce racks. Tho cate recorded during 


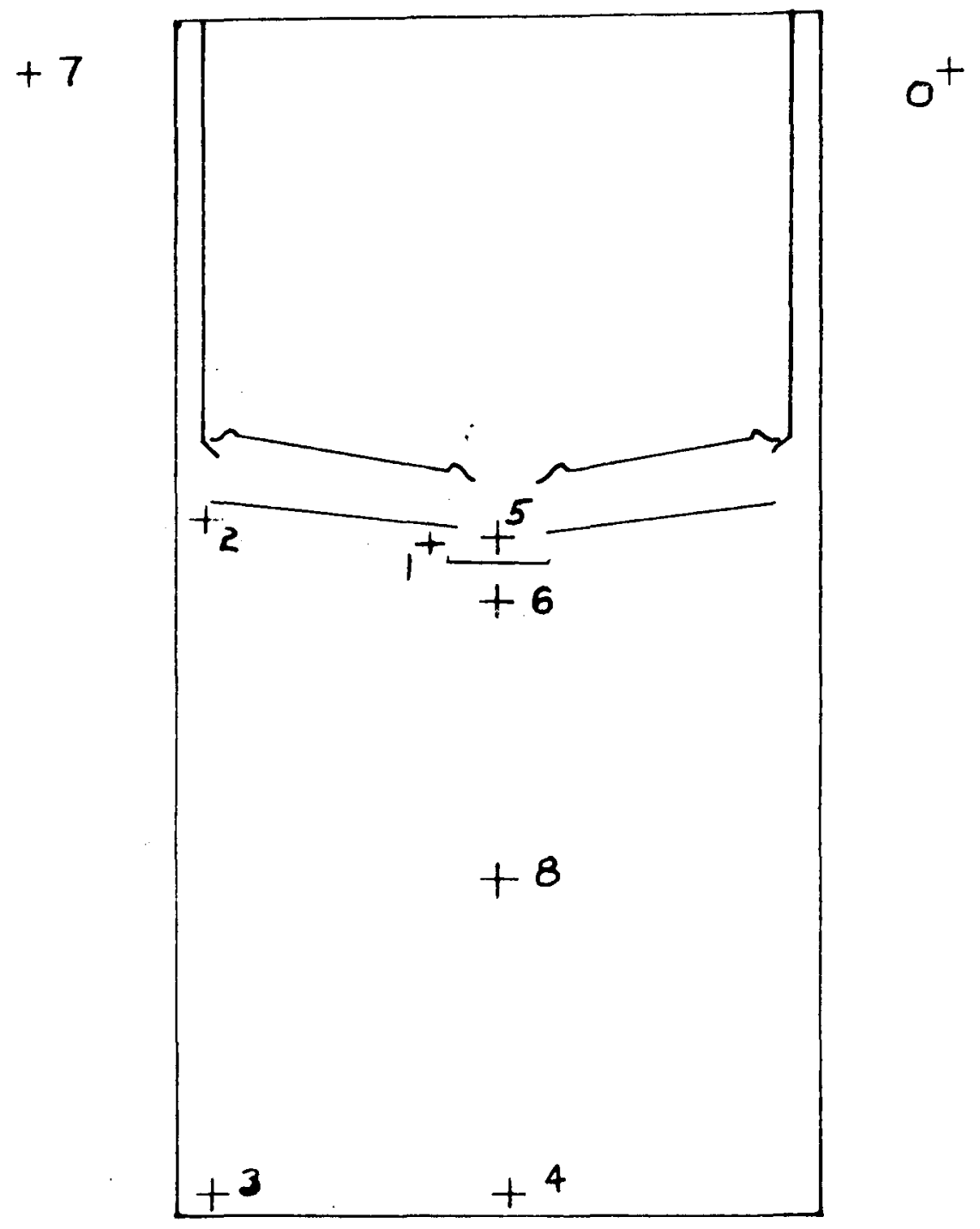

FIGURE 7 THERMOCOUPLE LOCATIONS FOR DATA OF TABLES II AND III 


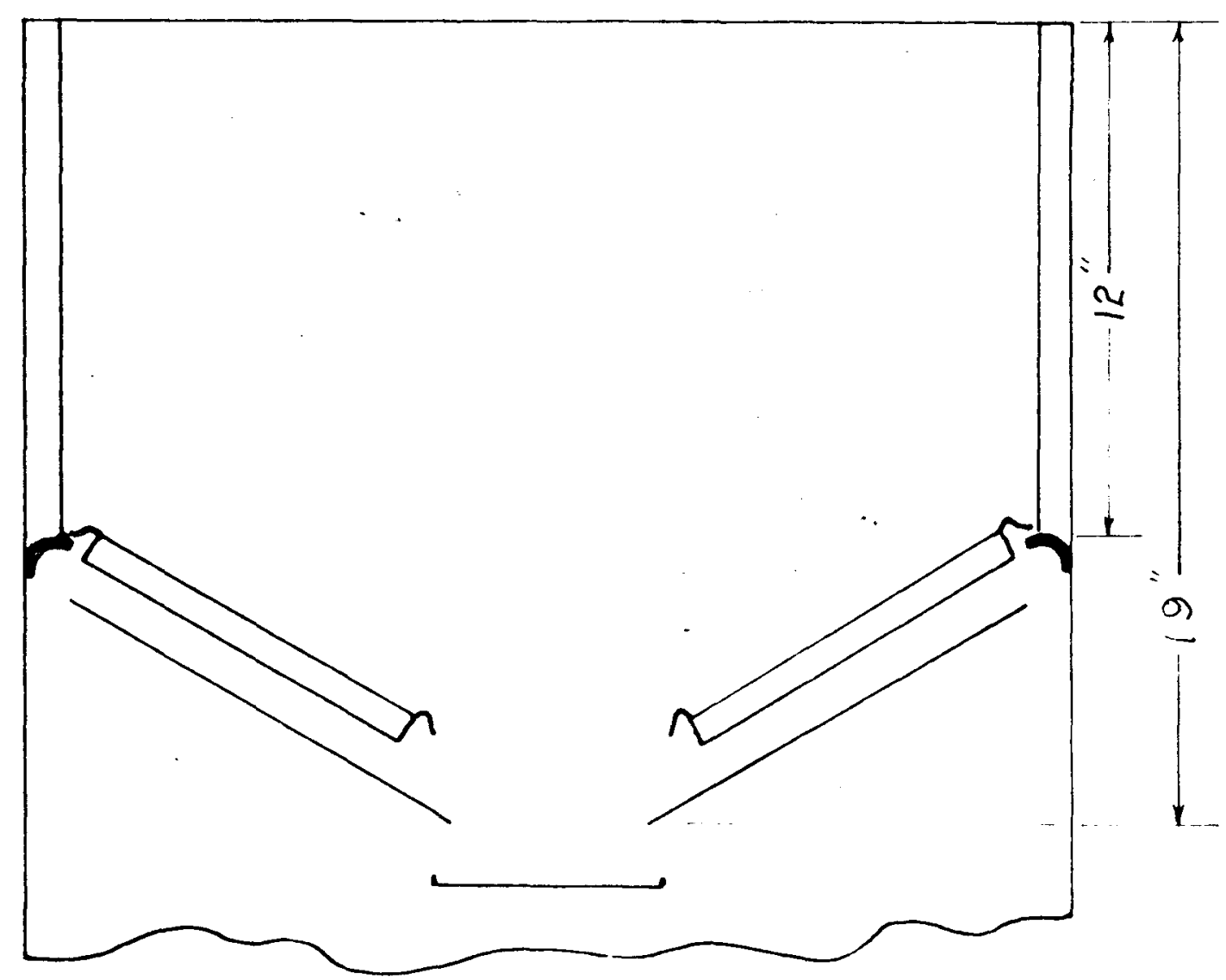

FIGURE 8 SKETCH OF ICE CHAMBER WITH STEEP RACKS 


\section{TABLE II}

TEYHEATUFES OF ICE EOX IN FOURT BEPIES TF TESTS

\begin{tabular}{|c|c|c|}
\hline $\begin{array}{l}\text { The rmocouple rumber } \\
\text { a. Shom in jigure } 7\end{array}$ & $\begin{array}{l}\text { Ice Chamber } \\
\text { Pull }\end{array}$ & $\begin{array}{l}\text { Ioo Chamber } \\
\text { Lor }\end{array}$ \\
\hline 0 & $86^{\circ} \mathrm{F}$ & $85^{\circ} \mathrm{F}$ \\
\hline 1 & 43 & 19 \\
\hline 2 & 62 & 54 \\
\hline 3 & 58 & 58 \\
\hline 4 & 80 & $\mathbf{6 8}$ \\
\hline 5 & 38 & 10 \\
\hline 6 & 18 & 80 \\
\hline 7 & 86 & 86 \\
\hline 8 & 80 & 80 \\
\hline
\end{tabular}


the riret tost of this eorles aro given in Table III, Ind1cating that once galn the tomperetures in the refrigerator had been reduced to setiefectory 10vel. The 10e gel ted riat and, in gonerni, offerod no diffloulty in releing. As the tents wore continued through sovars re101nge, new problew arose. The tee showed pronounced tondency to shift ita position toward of ther one ade of the chamber or the other. Because of the slope of the raoks, this shifting resulted in the upper aurface of the block assuming an Inelined position and counteracted all the advantagen of slat moleage that bad been enined.

The explanation for this shifting is the the rectangular 100 blook :o Inherently in otaticaliy unstablo wosition wan 1t is lylng horlzontaly on the inclined ice racks. It can be chown thet this case sutiofles the no theinatical oriterion of etat ic instability. Theoretlcally. thl unatable case al wo exiat od wen the less stoop racke of the original lee chaber wore used. Probably, the in- tablilty was not obserred in the latter case because tra tine roulred for the block to t1lt and raseb equilibrium wo much longer. With longer enulliorlun time arellable the block wa ole to lt and confore to the v-ahape of the rack before appreciable tilting was noticed.

sereral attespte wore made to force condition of equizibrium by restrainting the block. These restrainte took the forne of gulde vanes placed on the racke in such a 


\section{TABLE III}

\section{TENPETAURES OP ICE BOX IN FIFTH SEPTHS OF TASTS}

The rwoooupla number

as show in Fizure?

0

1

8

3

4

b

6

7

8

9

\begin{tabular}{|c|c|}
\hline 9,00 A.X. & $10,00 \mathrm{~A}, \mathrm{X}$ \\
\hline $84^{\circ} \mathrm{P}$ & $84^{\circ} \mathrm{F}$. \\
\hline 46 & 46 \\
\hline 54 & 54 \\
\hline 82 & 82 \\
\hline$\cdots$ & $\cdots$ \\
\hline 48 & 48 \\
\hline 80 & 49 \\
\hline 86 & 84 \\
\hline 80 & 80 \\
\hline 50 & 60 \\
\hline
\end{tabular}


position as to top aldoward motlons. Thoy proved uniforwly inefroctive because the ice tenced to "rlov" around this cort of reatraint.

Th1le further attempts to tablize the ice block might have proved succeaful, it was gerserally agrood that use of the 100 combor with toop racks in the housohold m! ght agrevate the stabilty problem. Consociontly, deolelon was reached to top work on the modifled foe chamber at this polnt ano to experiment with the "basket-type" chamber in wich no stability problem would be oncountered.

\section{Banket-trpe Ice Chember}

The oonvent Lonal ice chambor wa dosignod in suon - waner that whon relcling became noevasary, now block of lee was placed on top of the old or block. Thlo arrangerent necessitated e rat 10 surface at the time of reloing. The purpose of the basket-type 100 chaber is to provide a flat motal aurface for relelns. The basket as oribineliy developed by the Loulev111. TIn and Stove Company is shom in Figure 9. It consleted of number of peraliel, rertical metal pletes running ecrose the width of the 100 chamber, the plates being -paced about 2 inchos apert. In tho 10 eal case whon ro10ing is necessery, oldor blocke of seo will bo completely below the wotal ourface, perwlt ting the now block to be placed on the metel surface. 


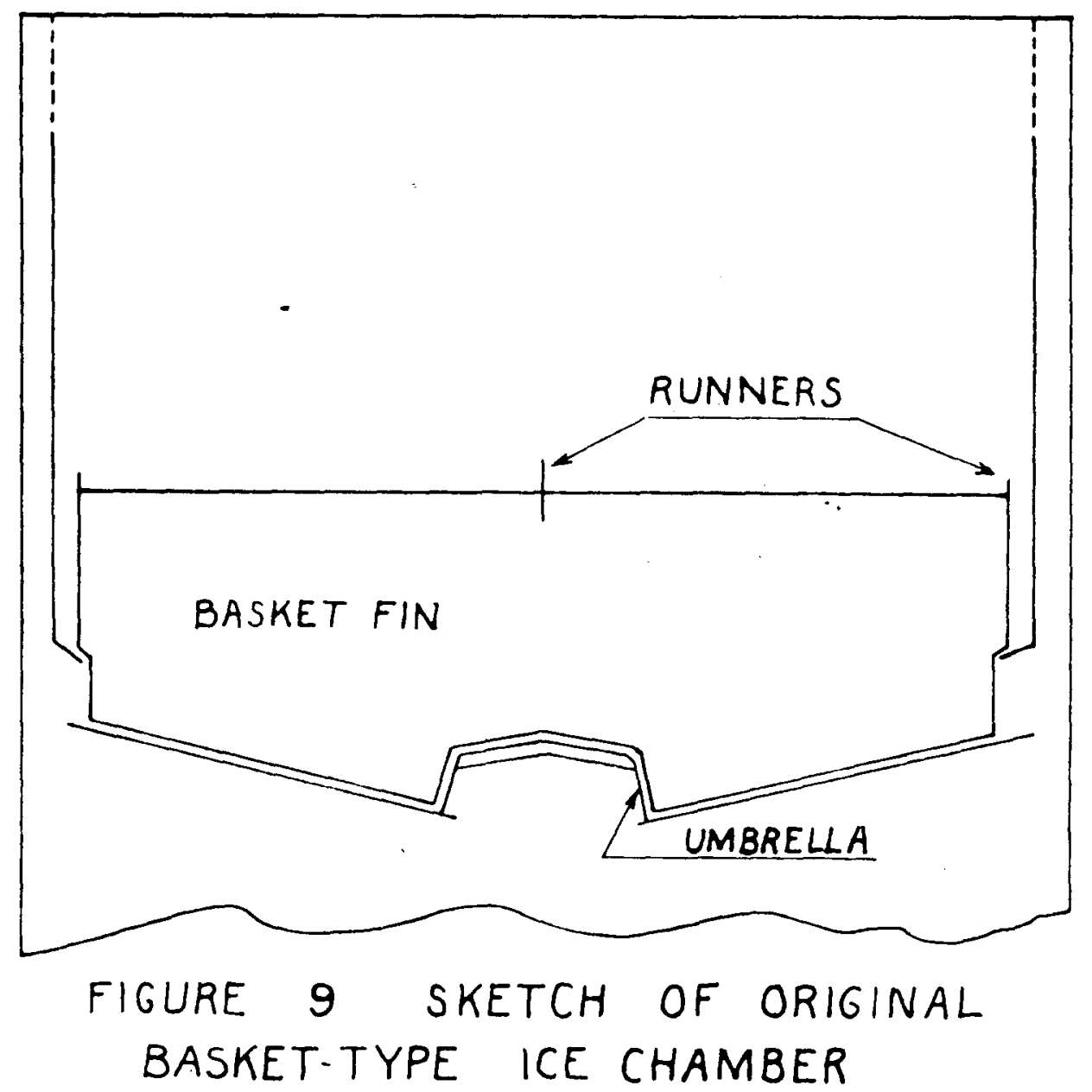

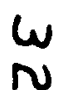


The advantege of this type of les ohamber is that flet meltage of the lee le not necessary, ano alr elreulation through the 100 chmber is permisulble.

\section{Sixth $\operatorname{ser} 10 \mathrm{~g}$}

In thl oerles the orlatnal baskot wa testeo for performance. The results are elvon in Toble IV. It can be seon that the temperaturee recorded wore completely satisfactory.

The in dirfloulty encounterod in this teat whe fallure of the 100 to melt cvor the down-draft. This wa objectionable because sce tended to eccumulate at this point, making relcing offficult. the amall alr-to-1ce temporature difforential existing th the ragion wa the cause of the defficulty.

To obta in a blgher tomporature aufferontial duot a shown In Figlir. 10 was 1rotulled in the lce chamber. The duct wa designod to calise a flow of comparatively warm alr through the region were the rete of 100 weltage was too 10\%.

Inltiel amoke teate carriad out with the duct in postion indiented a soady now of wrw air through the duct from the eront to the back of the refrigerator. While no

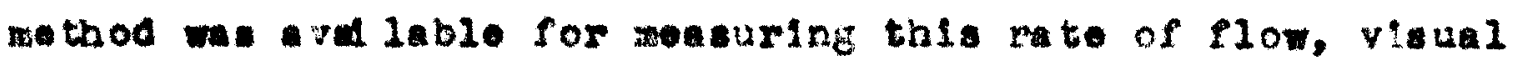
Inspotion Indic ted that it would be sufficlent to bive the deslred heat transfor efrect. 


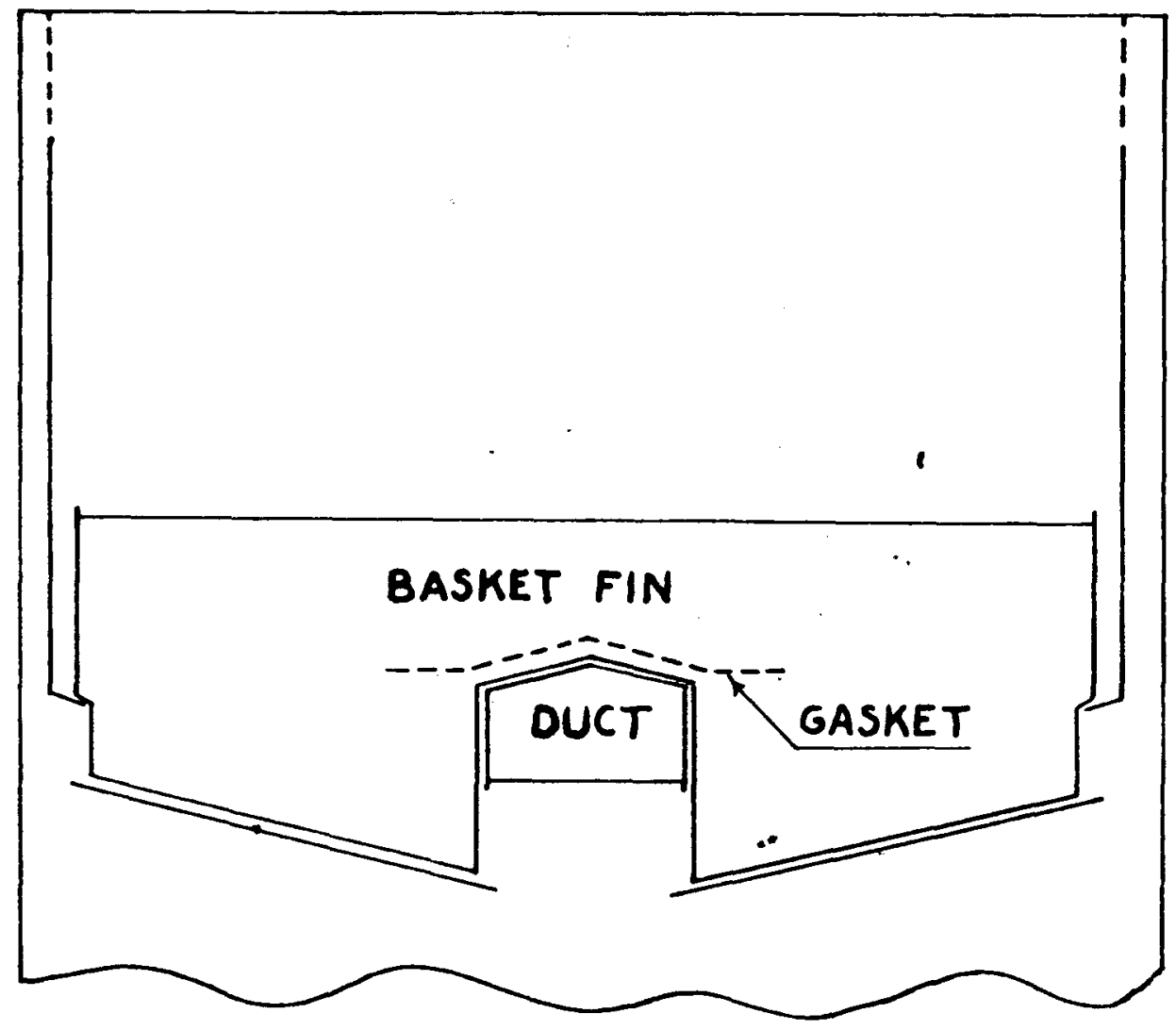

FIGURE 10 SKETCH OF BASKET-TYPE ICE CHAMBER WITH DUCT 
TABLE IV

TKUP BPATUEES OF ICR DOX WITH ORIOINAL BASKET CEAYBER

Thomocouplo Location

Firat oholf under down-draft

Four 1nches above bottom

side up-draft

Anbient

\begin{tabular}{|c|c|}
\hline $\begin{array}{c}6 / 2 / 48 \\
8.00 \\
4.10 \\
\end{array}$ & $\begin{array}{c}6 / 3 / 48 \\
8: 00 \\
\text { A.1. } \\
\end{array}$ \\
\hline $42^{\circ} \mathrm{F}$ & $44^{\circ} \mathrm{F}$ \\
\hline 45 & 47 \\
\hline 40 & 80 \\
\hline
\end{tabular}

8b

84 


\section{Sorenth Sor10e}

Followino the prol 1minary smoke tests, tomperature toat was cerrled out us Ind the nodirl od baket chamber wth a duct. Tenferntures recorded during this test are givon in Table v. Two algnificont facto wore rovolod durInis this test: (1) It we learnod that the loe was oxtromely consitive to chariged in the lovel of the ice chambor. A -21ght slope of the racke wa capable of causing the lee to enirt ite position aeveral inches. (2) the metal area on which the 10 reated wo uld heve to be reduced to a minimus. The re to alch the ice dasconded through the gride wes dependent largely on this area.

To reduce this grid area to minimum, overy other rib in the grid was rewoved, runners were removed, and the 1ce chamber retented. The results recorded showed acceptablo perfromance characteristics in al I reapects. At this point, the test were ond ed. 
TABLE V

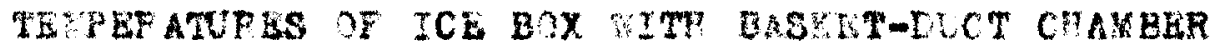

The rnocouplo

Loeation

Firat nole

und er down-

draft

Four Inohes

above bot tom

side up-draft

Ainb Lont
$6 / 22 / 186 / 13 / 186 / 14 / 48 \mathrm{Re}$ $10,00 \quad 12: 18 \quad 8,00$ iced

A.K. P.X. A.K.

10.9.
$6 / 14 / 486 / 18 / 48$

$4,30 \quad 8: 00$

P.L. A.H.

$41^{\circ} \mathrm{F.} 48^{\circ} \mathrm{F.} 44^{\circ} \mathrm{F} . \quad 42^{\circ} \mathrm{F} .42^{\circ} \mathrm{F}$

43

16

40

44

44

46

40

80

48

48

86

84

86

86

86 
CONCLUSIONS 
A number of valuable conclial ons can be drawn from the reaults obtained in teating the two types of lce chabera. reats of the orleginal ice chamber showed

2. Satiafactory tomporatures cen be mintainod in the refrlgorator provided the circulation 1. adonute. To obtain adonute circlilation, the the rmal hod must bo as groat as possible, and slow rostatence must be redued to a minimam. 2. Iat moltage can be obtalned provided the fce chamber is accurately leveled before use and no apprectable circulation lo perwitted in the upper part of the ice chabor. Quskets and soale must be used to proront this circulation, and plates must be rastoned to 100 racks to provent undorcutting or upward circulation of alr.

3. No deac ir spaces should be permitted to exlst in contact ith the bottom of the 1ce. These ir spaces Insula to the lee from the olrculating alr and provent satisfuetory molting.

4. Static indtablity of the 100 block may prove troublosone if V-ahapod lce racks aro used, result ing in tlppling of the lee block. Some inatablilty lo lnherant in this type of rack, al though it way not be serlow at a vory slight slope. Ice gulaes used to prevent unatablo eblfting of the 1ce have only 11 mited efrect.

5. The baket-type 1ce ohe abor glvos lower refrigerator temperatures than does the $v$-ahapod rack because circulation over the 10 nesd not be provented to insure rlat mel ta $8 *$. 
6. The t1ae roquired for the lo to atak below the level of the besket surtace and pormit roleling dopende on the nurber of ribs and runnors in tho besket.

7. Fopld wolting of 1 co in tho center of the besket, where tomporaturo defforentials are ordinarily toc 10w, oan be ootainod of installing duct at that point to bring ware air in contact 1 th tho ico.

8. If basket-type 1ce chambers wre to operate properly, they wast be carefully loveled before use. 


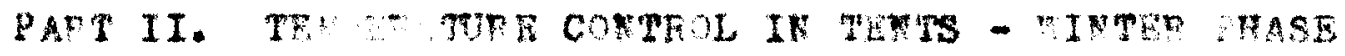
INTROLUCTIOE 
The mesntenance of comfortablo conditions in tent-ge in moderate or cold climale winter operetions reaulres a supply of noat to the alr within tho tonts. Iven with a soablo soat input to the tent, it is frouontly impoesiblo to malnta in comfortable conditiona; fabric layors, in adoltion to thet of the tont structure itsolf, aro neoded to offor reslatance to heat losseo.

In the intor of $1946-17(1)$ teete in erected milltary tonte onulpped wt th 11ner: were conducted to establish the relative offectivenese of linero of alfforent moriale and construction. In this work conventionel no low proflle Irers of ox. white cotton sheoting, 7.9 ox. cotton, 0.I. 7, and ane-half inch thicknose of flborgles botwoen two layers of 4 oz. cotton wore examinod. A11 the iners wer offoctive In roducing boet loosee, and relatively little difference was deterted botween liners mede of fabrscs of difforont welent and color a long a the tabric construction wa cosontlally the same. The Ilnor containfnge the floorglas between the two leyers of cotton ahoetling preved to be the best overall Inoulator. Fowever, the use of this lattor liner was libited by 1 th buik ond to aone oxtont by 1 ts total welght.

In vie of the reaulte obtained w th the Iiner conteining the floorglas inaulation, an ttempt wa mado to destgn a liner baving an insulating value oomparable to that of the two lagers of sheoting and the one-hale inch thickness of fibergles whout the ol andrantageous weight and bulk. 
A conelderation of the hout transfor asecheriam through the liner and tent and the results of provious tests with tente -quipjed with liner. Indicated thet the concept of placing the wajor realstance to hat flow in the ir flime adjecent to the rabric surfaces wa aplicable in the cese of the orocted tonta. This aproach lanorad the roslatance offared by the sebrie ituelf and whe consistont with previous experimental resulta. These viewe thon permitted the dostan of liners composed of eovoral ligers of lightwelght cloth, providing addtional alr filme for heat lose radution without unduly incrossing the welight and bulk of the IIner. Accordingly, two- ano three-layer liners were manufactured by the Joffersonville cuarterraster ropot and erected in large wall tente. The results of tests with these assemblice were then compered with provious reaults of exporlante wh thele-layer liner and the liner containing the one-half inch thlckness of fiberglas.

In this same sorles of tosts tho auntity of reat lost through the ground, as woll a the varlation of the heat lose 1 th humldity change in the tent, wa investigated. 
TOPORETCAL 
Txporimentations in Inter pheso tomperture control in tentage have balcally the object of securing rellablo deta pomitting the beat overall design of tenta for cold clim te uage. For thlo purpose calculationa and correlation of temporature data can be campoc out loadig to overall coefficiente of heat transfor, overall conductivity terwa, or crerell thermal resistance teme. Then oomparison of the nurerical values of those torite for elvar. tont and 11 tor assomblios ahow the ouporior itome as for a hoat 203 and comfortable terperature antenence is concernod.

From the cata obtained in these winter phase studies, overall cooficlents of heat tranafar are calcu1atod. Rowever, snce the data rere obteinod in tints orectod outa1de, whore the walntenance of conatant conditions ras lopossiblo, cortain calculations re noeseary to eliminato vartations in teat conditione that would prevent good compar 1 aone.

GHO UWI. LOSSES

The total beet input to the tent aus leave -1ther through the fabrict, seame and closurea, or through the ground. sven though the hent los through the ground is a variable quantity. the eutablichment of reaconable value 
for this lose allowe a more ecurate calculsilon of the heat lose through the tont ard Iner asseably. Two tecininues were deviaed for the evaluation of the ground 10s ses. The Plret wethol was the location of theracoupla in tho eround at ramous depthe cown to one foot as ahown in lgure 13. 3ince the amount of heet rlowing into tho ground is, among othor factora, anction of the terperature of the air 1mmediately abore the ground anc the eround temprature, both variableo in these teata, it is possiolo to calculate, within 11alte, the hoat flow into the ground by ualng the following couation:

$$
C=\operatorname{Top} \Delta t
$$

where

$$
\begin{aligned}
& \text { C cuantity of hest, Bro } \\
& \text { - wolght of ground. Ib. } \\
& c_{p} \text { apoolf1c hat of sround, fru/(1b.) (Op) } \\
& \Delta t \text { - tomperature rao of the soll, } 0 F \text {. }
\end{aligned}
$$$$
\text { The aecond method - quit similar to the method }
$$

uning the lchols heat 1 lon reter(2) - gave more satisfactory resulta. Two the rmocouplas 1rbedded in the opposite races of a wito pine bone wh one fsee in contact with the bround and the upjer face at esround lorol expoaed to the alr within the tent permitted the reasuremert of a temperature gradient. A knowlodgo of this tomparture cirference, the diatence between the two thermocusples, and the tharmal conductivity or the boerd allows the use of the equation for host flow by conduetion. 


$$
a=\frac{k \Delta \Delta t}{x}
$$

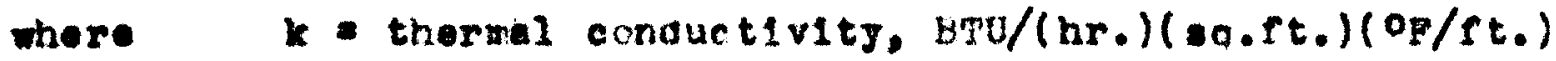

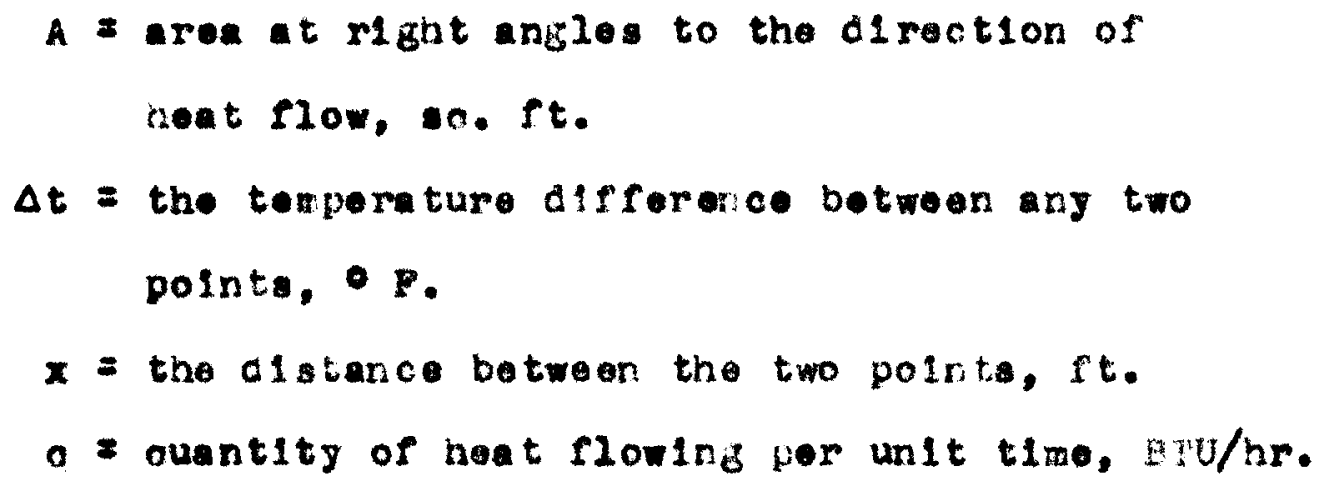

\section{SOLAP PAIIATION}

The teaperature relized within tont of givon total hoat input, as previously deacribad, aro greatiy inrluenced by elar or sky radiation. Luring the day, radiation rrom the aun and/or aky add hest to the cent: et night the tont 100 as hat by radiction to tre cold sky and surround $\ln 8$

For good comperians of test restits obtalned on differont days and nights, it wa noceasary to nceaunt for this radiat on. For this purpose, reforence tent ident1cal to the test tont wa usad and onulppod with thermocouples so mrangod the readini could be wad in the tout tont. Th1s roforence tont was not internsily heatod but allowed to

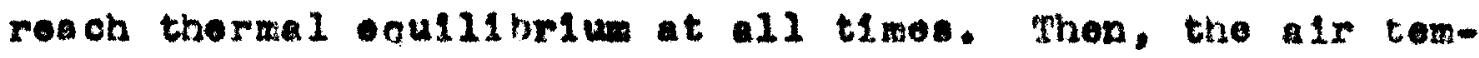
perature within this tont was the net result of radiation and 
convection, 1.0., In the digtime its torpecature tends to be Increased by redition and lowored by cotroction, wile at night the rovoroe is true.

since the teat tent and the roforence tont ware Idontical, it could be asoumed wth rasonable accuracy that the overell heat transfor cofficlonts were tho ame. Therefore, the total he input into the teat tant was the sum of tho somsurad heat inpute and the not offoct of the hoat from colar radiation.

The neat lost by the test tont can be ropreserted by the eavation,

qt $=U_{A}\left(t_{1 a}-t_{\text {on }}\right)$

where

$$
q_{t}=\text { hent } 10 \mathrm{t}, \mathrm{Brv} / \mathrm{hr} \text {. }
$$

$U$ overall cofflcient of nont transfar from tho insia alr to the outalde ar, aru/ $(\mathrm{hr} \cdot)($ sa.ft. $)\left({ }^{\circ} \mathrm{F}\right)$

A = eren of the tant rabric, an. ft.

$t_{10}=$ everage inst de elr tompere ture, $0 \mathrm{f}$.

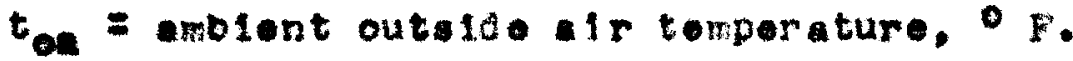

The hoat rocelved of the roforence tent fror solar radiati on ray be aseumed ath amall orror to be lost by convoction, so thet at omulilorion

$$
q_{r}=t_{r A}\left(t_{\text {mr }}=t_{1 a}\right)=q_{0}=u_{c}^{A}\left(t_{1 a}-t_{o a}\right)
$$

wore

$$
\begin{aligned}
& q_{r} \text { - hent recolvod by raulation, hou/hr. } \\
& q_{c} \text { - heat last by convecti } n \text {, wo/hr. } \\
& u_{r} \text { - overall radation coeffesent, arw/(ar.) } \\
& (\text { en.ft.)(op) }
\end{aligned}
$$




$$
\begin{aligned}
& \text { u: = overall corvection coefflctont, } \mathrm{BTu} /(\mathrm{mr} .) \\
& \left(00 . f t_{0}\right)(0 p) \\
& A \text { = rabric aroa, sc. rt. } \\
& t_{w r}=\text { mean radiant tomperature, } 0 \\
& \text { tia = arerage Inside alr temperature of tho } \\
& \text { reference tent, } 0 \text {. } \\
& t_{\text {on }}=\text { abbiant outside ir tempergture, } 0 \text {. }
\end{aligned}
$$

Then, the tote 1 hot lost from the test tent through the fabrie becores

$$
a_{\mathbf{z}}=\mathbf{q}_{\mathbf{b}}+\mathbf{q}_{\mathbf{z}}
$$

where $q_{T}$ - the total het lost through the rabric. BTt/hr.

$a_{h}=$ the net hest applied by the neters, FrU/hr. $q_{r}=$ the neet seined by radiation. Em/hr.

or $\quad q_{\mathrm{h}}=q_{\mathrm{r}}-q_{\mathrm{p}}$

since the rofererce and test tenta are ldertical, value of $q_{r}$ can be substituted from the roforence tent glving the oxpression,

$$
q_{n}=v_{A}\left(t_{1 a}-t_{o n}\right)-v_{a}\left(t t_{1 a}-t_{o n}\right)
$$

and ince the tonts are ldent!cal, 0 and $U_{0}$ can be taken eaual with $11 \mathrm{ttl}$ error, or

$$
a_{\mathbf{a}}=\mathrm{uA}_{\mathrm{a}}\left(\mathrm{t}_{1 \mathrm{a}}-\mathrm{ta}_{\mathrm{a}}\right)
$$

In other worda, the coefficlent of hot transfor from the in- lo air to the outaide a ir car be caloulated from the net heat uppliod by the toaters, the rabric area, and the alr temperature difference betweon the test and reforence tents. 
Whon the okj was novily overcant, day or nIgbt, the reference tert tenperatures appronched the ambiont temperature and calculations could bo rade in the ueual maner wthout the une of the refererco tent.

Al though tho wethod we aptisactory for calculating the datu obtalned in these teate, the teohnioue would not apply if the urface tomperetures of roforence and test tente difrored appeciably.

Figure 11 ahow a comperison of these surface tamperatures for a tgpleel day.

\section{INIVIFUAT COEETCIEYGS}

The ineulating ralue of the tent or tent and liner assenoly depends, awong other thinga, upon the quantity of hoat transform per unit tia por unit area of tent fabrio under a given temperature diferential driving force. Thls value 1a fundamentally a property of the rebric and the onvironment in wich it existo and can be repreaented by a resistance term, arios of renlatance terme, or by conduativitioe. In these atudies the conductivity concept has been used, and overall coefriclents of heat transfer have been calculoted. Vlgh raluos of the a coeffletents inalcate high neat losses, and low values indicate losser hent losaes or a better Inauletine aystom. 


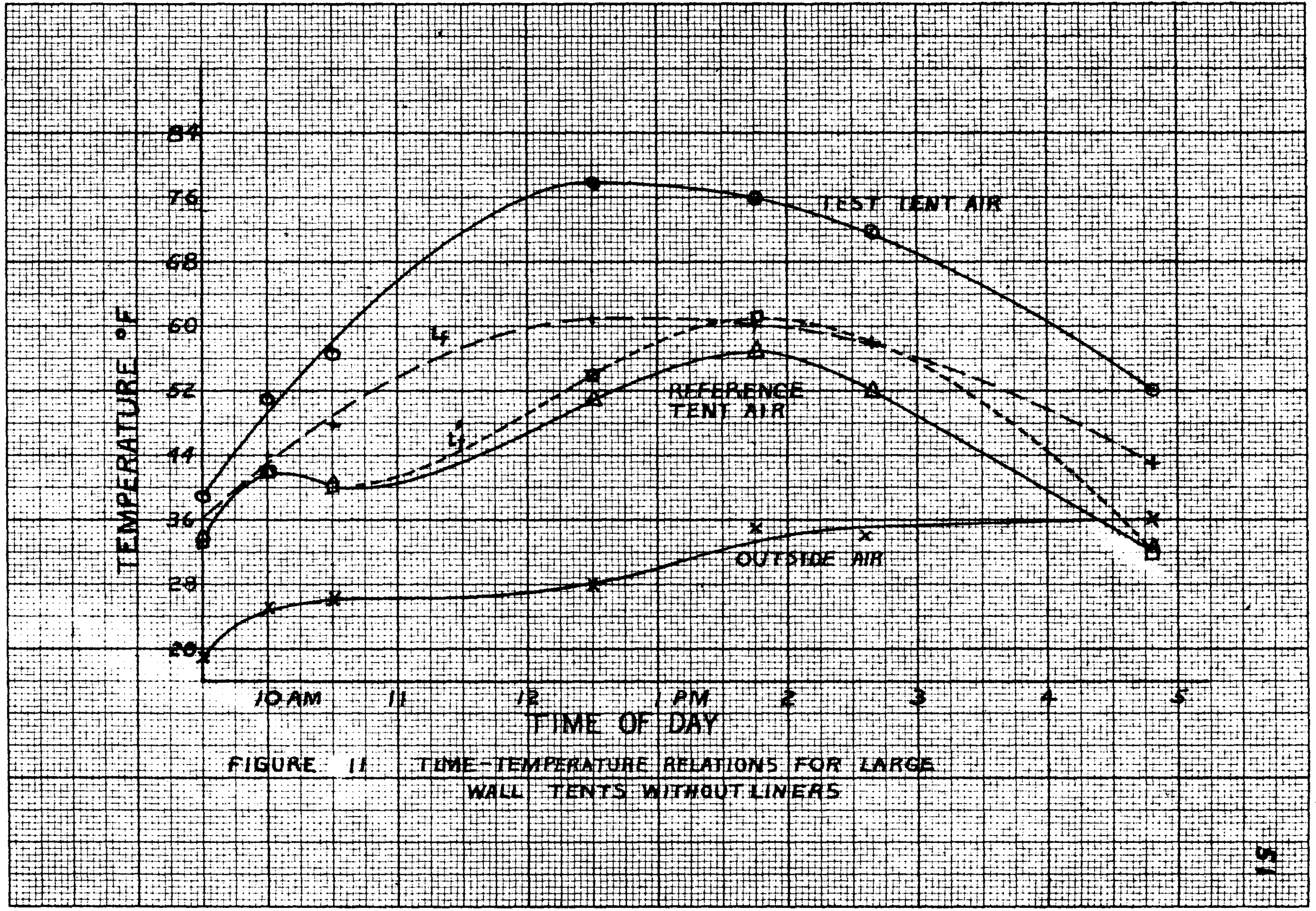


Just as the totel thernal rosistance of a heat tranofer oyaten can be cal culated from individual realatinces, a can the overall coerficlerts of heat tranerer bo calculated from the Indivioual coefficionta. In this work the ontire rosistance to the het loses ha bean considered to 110 in the afr flima with noelfelole resistance in the fabric itself. Accoralngly, the overall coefflclonts of bet transfor can be calculatod frow tro ind ividual filw coefficiontg.

In this case, where, tho overnil coefficient of heat transfor corresponde to hout transfer frow alr ineloe the tent to a Ir outalde the tent, the film coefricient correaponds to the heat tranater, for example, fror the air within the tent to the tant fabric. Nowevor, wibin the tost tont the procese is complicatod by hot tranefor to the fabrle by convection, radiation, and conduction; and for a smpirication of the conoopt, all hoat tranafor io encoldered to bo by convection and radiation. therefore, the hoot traneforrod by convection lo characterszed by a convection f12m coefricient ano that by radiation. by a radiation coefficiant. The beat reoleted from the suleld of the heating unlt can bo calcula tod by the oquation.

$$
a_{p}=0.172 A F_{\theta} F_{a}\left[\left(\frac{T_{0}}{100}\right)^{4}-\left(\frac{T_{f}}{100}\right)^{4}\right]
$$

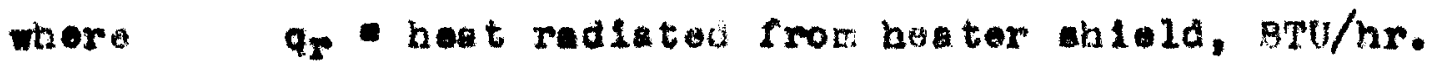

$x_{3}$ - tempere ture of eurface of heating unit, 0 R.

$T_{f}=$ temper ture of the fobric recelolie the radiation, OR. 
A - aroa of the hoaling undt, soft.

$P_{0}=$ osiusivity factor (in this case, 0.276 for groy galvanlzed sheot 1 mon) (3)

$F_{e}=$ rea ractor (In tials cese, 1.0)

Ith the knowlede of ar from the onuation above a ration coefriciont can bo calculatod.

$$
\begin{aligned}
& \text { Qr }-b_{\mathbf{r}} A\left(t_{1 a}-t_{\mathbf{r}}\right) \\
& \text { wiser } h_{r} \text { - Insio radiation coersictent, erv/(hr.) } \\
& \left(\text { og. } \mathrm{tt}_{0}\right)(\mathrm{op}) \\
& \text { A area of the tent in aght of the houter, } \\
& \text { on. It. } \\
& t_{1 a}=1 n \text { 1se wir tomporature, } 0 . \\
& t_{f}=\text { fabric temparaturo, } O p \text {. } \\
& \text { The convoction cofriclont car be calculatad usine }
\end{aligned}
$$$$
\text { the cenvertional equation, }
$$

$$
\begin{aligned}
& a_{c}=h_{c}\left(t_{1 a}-t_{f}\right) \\
& a_{c}=\text { hoat traneforred bj convoction from inside } \\
& \text { ar to the fabric, } w_{0} 0 / \mathrm{hr} \text {. } \\
& h_{c}=1 \text { insio convection coeffictert, } 0 \mathrm{Tu} /(\mathrm{hr} .) \\
& \text { (an.et.) ( }{ }^{\circ} \text { F) } \\
& \text { A aroa of tont fabric, ac. It. } \\
& t_{1 a} \text { - 1nela alr temperature, } 0 \mathrm{~N} \text {. } \\
& t_{f} \text { - rabric temporature, } O \mathrm{~b} \text {. } \\
& \text { The thent loss fror the outsion of the tont by radi- } \\
& \text { ation wa obtalned by consiuguino the tont fabric as radiating } \\
& \text { to the surround Ing at an average temporature gproximitely }
\end{aligned}
$$


equal to tho ground terperire ture outside the tent. Ueine the radiction onuation.

$$
o_{\mathrm{r}}=0.272 \mathrm{~F} \mathrm{~F}_{\mathrm{a}}\left[\left(\frac{r_{\mathrm{f}}}{100}\right)^{4}-\left(\frac{r_{\mathrm{r}}}{100}\right)^{4}\right]
$$

where

$a_{p}=$ heat lost rrow tent arface to surroundings, BTU/hr.

$A$ aroa of tent fobric, oo. it.

Fomiosivity factor

$P_{\mathbf{a}}=$ arae factor

$T_{P}=$ fabric temperature, $O \mathrm{~K}$.

$\mathbf{z}_{\mathrm{g}}=$ tempere ture of surround $1 \mathrm{~g}_{\mathrm{g}}$, taken equal to outside sround temperm ture, $R$.

- value of qr was obtained. Then, using this racis tion heat 10aa, value of $h_{r}$ wa obtalned from the oquation,

$$
a_{r}=b_{p}\left(t_{r}-t_{o r}\right)
$$

where $h_{r}=$ radition coefficlent for outalde of the fabric, Ruthr. $)($ so.et. $)(\mathrm{Op})$

$A=$ area of the tabric, eq. ft.

$t_{f}=$ rebrlc tosperature, o $\mathrm{F}_{\text {. }}$

ton outalde ambiont texpere ture, $0 \mathrm{~F}$.

subtracting tho outeide radition lose from the total 108 through the fabric, value for extermal convection losses is obta1ned. Ualng this value as convection loss, convection Plim coefficient can be calculated for the external surface wth the cauation.

$$
a_{a}=h_{0} A\left(t_{r}-t_{o n}\right)
$$

glving a value for ho 
A srouping of the four cosficients a follow for the establishment of an overall coerficiont

$$
\frac{1}{0}=\frac{1}{n_{c}+n_{r}}+\frac{1}{n_{c}+h_{r}}
$$

EIves value of $U$, the ovorall coerfletent.

Thle thed of calculat ing individual coofficlonte and thoir use in ostablishine value of the ovorall coefficlont, agreaing well with those ralues obtalned by other meana, wes conaloured good abstantiation of the validity of the procedure. 
HXFLIAEMAL 
In the winter phese temporature cortrol studies, two large wall tenta were the bale unlto used in the tedte. These tents were enulppec wth sround olothe of 12.2y o. duck with J.C.I. 242 rinish, 11ners, andelectric beters. Throe different types of 11nera wore used in the investigat1on: (1) 3.6 or. cotton, 2 lagersol cloti; (2) 402. cotcon, 2 lagora or cloth, Inver fabric, dark groer, vinyl conted; and (3) 4 or. cotton, wite, three layers of cloth. The IInere were ausended within the tente so that an ir space of epproxintely eix Inches was formed between the tont and 11ner. The evspenefon of the Iinere wes by weana of tapes over the ridge pole and tapes through wetal rings on the fabric of the tent. whe linere were of sufriciont length to close the alr apece betweer the tent and the liner at the ground. The ends of the tents and I1ners (or fronts and beck) were clood by snap fastenera or band cowing leaving only onough clearnnee for a very low entrance to the tent.

The two-layer oxperimental linars were constructed Wth lines of titchine olint inchea apart runnine from the ground to the ridge. The faoric toward the interior of the cent neavred ton inches betwoen the atitoulng so that there wa a seration of the two layers of cloth over noet of the Iiner. In the case of tro three layor 12roro the sare fabricaticn techniques were owployed. Nowever, tho stitching did not peretrate the three layers, 1.0., the 2 lno of stitching 
for tive outer and intermediato layers were sidway between the Ilnes of etitchine for the intermediate and Inrer layere. A aketch of the arrangerente of the etitching and fabrice in the tents with two- and threo-lager 1 inors 1. shown in Figure 12 and 13.

The noating un1te for thea toat tents cosided of eix 56u-wett cone heatere win socket bases mounted on transite and shielded 1 th galvanizoc iron to provent alrect radition to the fabric. A $220-120$ volt outlet switch box fermitted connections to the beatera and a 11 ght ource. 0ccasionaliy, two of these elx un1t heater esenolios rere ueed in parallel for increased hent input to the tent. The ectual heat input to the tont by the tio ter was obtained from voltreter ono anoter readinga.

In ado:tion to this hat ingut, a 11ght bulb suppl1ed the neceseary 1ight ing, ano two occupante remained in the test tent during the tests. Sinco the occupants were IIghtly clothed and wore or 1eso et reat, their Individual neat output was about 100 ETU per hour(\$) Thorefore, the wattage of the 11 ght buls and the bodlly neat of the occupanto were edded to the heat aupplied by the heaters to obtain the total ract input to the test tants.

Previous inter phase studieg shoned that the arorage Inside alr tompe ture of large wall tents colncided wth the ar temperatare at 3.5 foot above the floor 5 ! In these teste four therrocouples, och 4 reot rrom corner of 


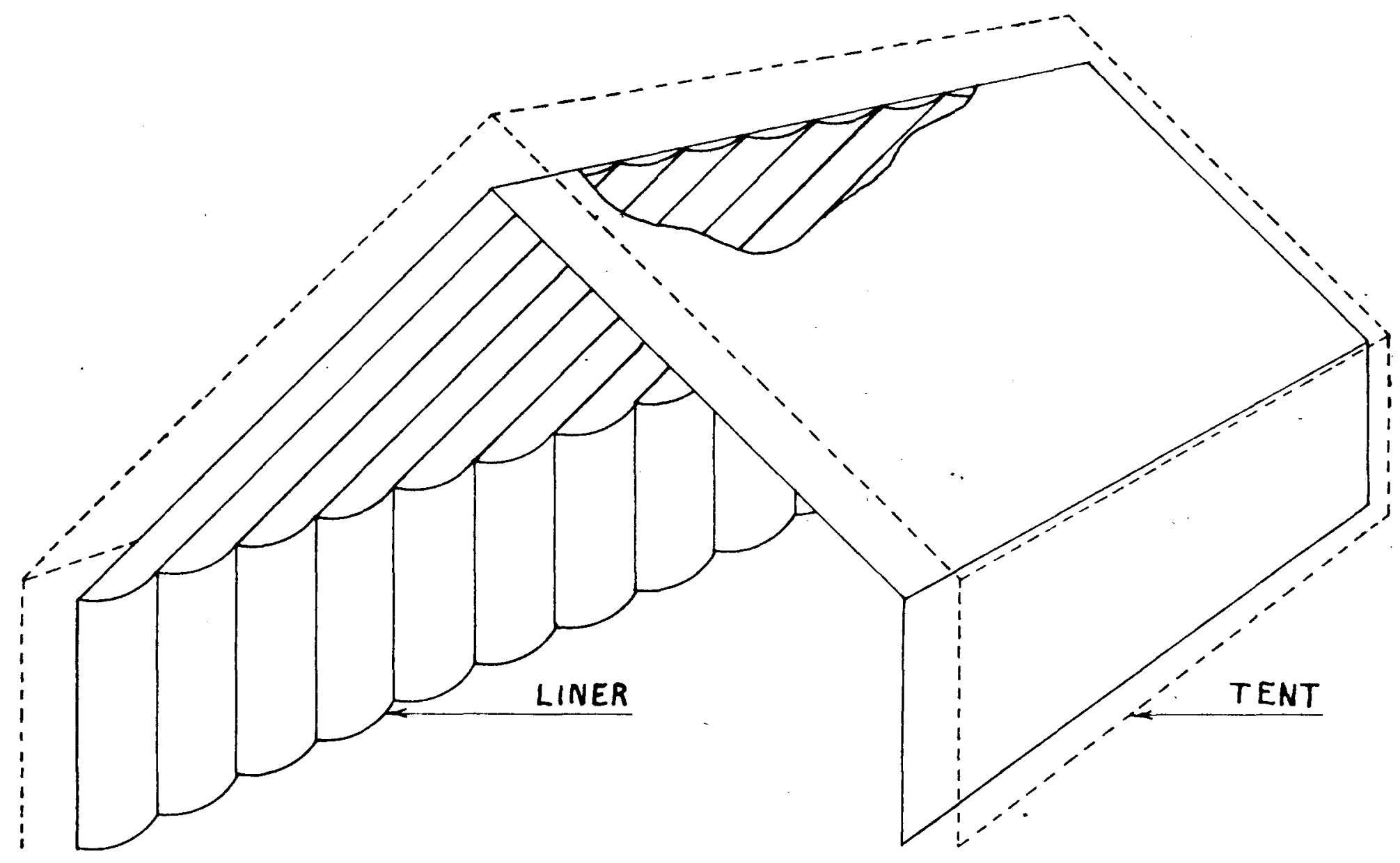

FIGURE 12 OIAGRAMMATIC SKETCH OF LARGE WALL

TENT WITH TWO-LAYER LINER 


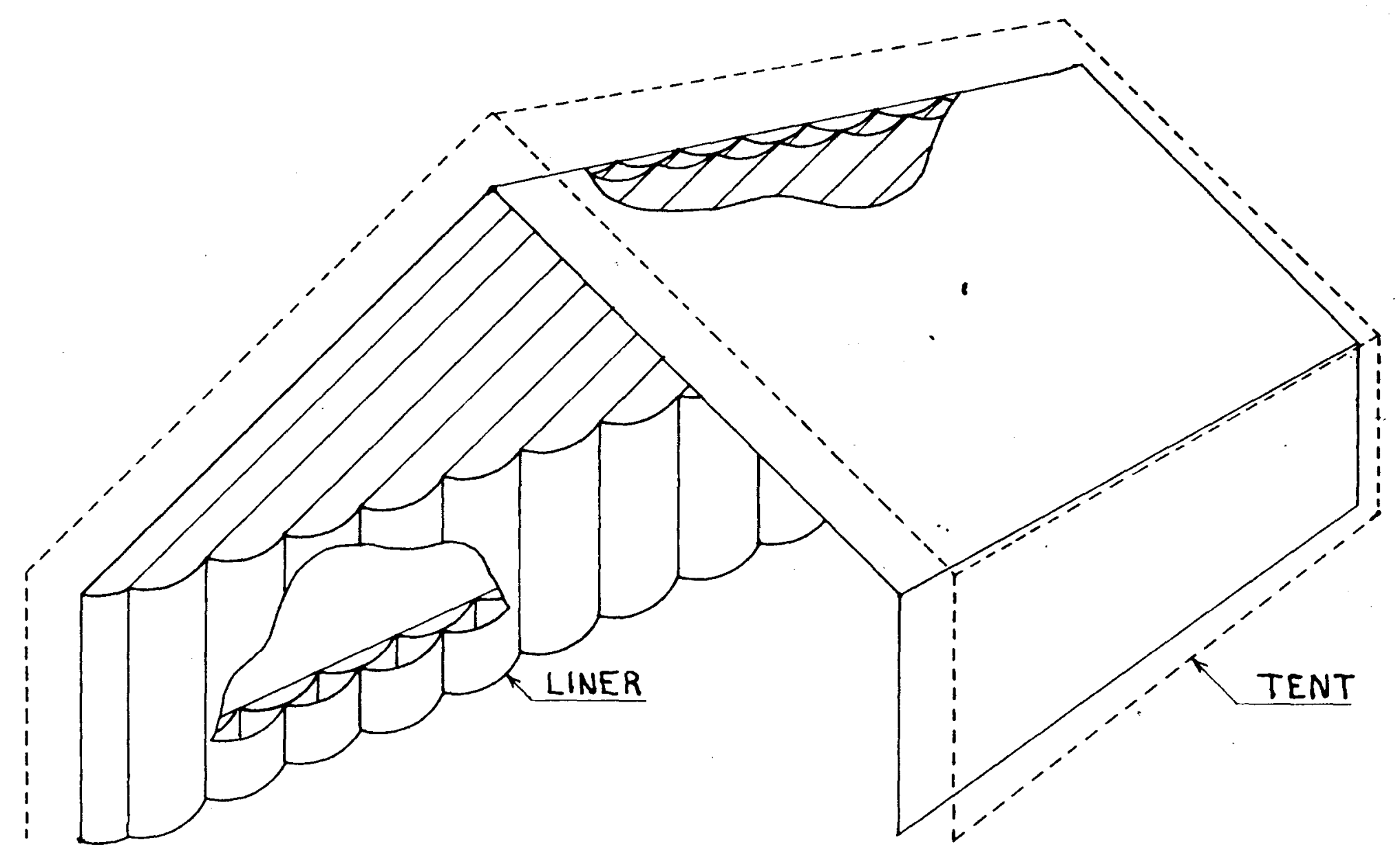

FIGURE 13 DIAGRAMMATIC SKETCH OF LARGE WALL TENT WITH THREE-LAYER LINER 
the tent at the 3.8 reet level anc connected in parallel to the potentlometer, were used to ind ice te the avera be alr temperature -ithin the tent. Likewiat. In the case of rabric toperatures, the thermocouples wore sown to the fabric of the tent or liner ac that ench therrocouple neasured the tempersture of an onual area of fabric. These tberrocouples, connected in parallel to the potentiometer. gave the average rabric tapereture in a angle raading. All thermocouplos ware made of 30 gage copper-constantan wire. Usine circults of this type, groeter opeod wo posalole and in all probability greater ccuracy. ince in the two minutes renuired for making all readings, changlng weather could herdy have produced measurable temporature changes.

Alr voloc:ty nomeurenerts in the vicinity of the test tents wero obtained with threo-cup anomometer seven feet from the groupd.

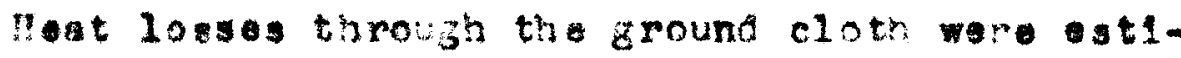
wated frow temporature meaurerents with thermocouplog inbedoed on both ades of a plus soard $\left(3^{\prime \prime} \times 4^{\prime \prime} \times 9 / 16^{\prime \prime}\right)$ beneath the ground cloth. Thls hat flow reter was placed nlown between the center and dge of the tent so that readinge would indicate an are ge heat how into the ground. Thermocouples irbedded in the eround intervis acwn to one root gave mene of ohecking the hout rlow reter.

In carpyiri out the winter phase teats, the tont were erectad with ridge polea forth-south and quippod with 
the apparatus describec tove. Thermocouples and tbemome-

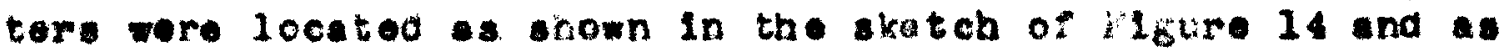
deacribed in Table VI.

In order to evelue the influence of oolar radiation properly, tent loentical to the tost tont wa orected soven tot froa the towt tent. Thls tert, reforrad to the refererce tert. wa completely closed arc all themocouple wres were corrected to aelector switch with in the test tent.

A21 data were obtalned after the temperatures at

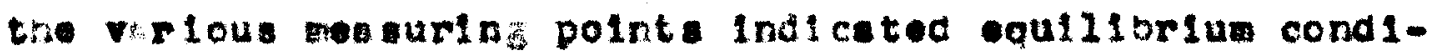
thone and were recorded on the data cheta a shown in Figure 16. Ind velocltiea vere reonded before end after each series of runa. However, in post casos the wa velocition were $10 \mathrm{w}$ mough to be nel1glole.

Whener poseloze, the tosto wor crnducted in clear weather if very 11t to wro. In order to rininize eolar radit on effocts, moming and oroning mus were made, a wall a a number of nlght runs. A total of twenty-two tosts, each conelsting of ceveral groups of equilibrium runs. were sade et approxistely one hour intervala. The ammarized date for these testo re som in Tables YII. VIrI and IX. Qround loas value were found to vary from 300 to 2100 ETU Der hour for the varlous test conditione with a relative valie of bout 20 fer ont of the total heat input to the tent. There was actually sorie variation in those 

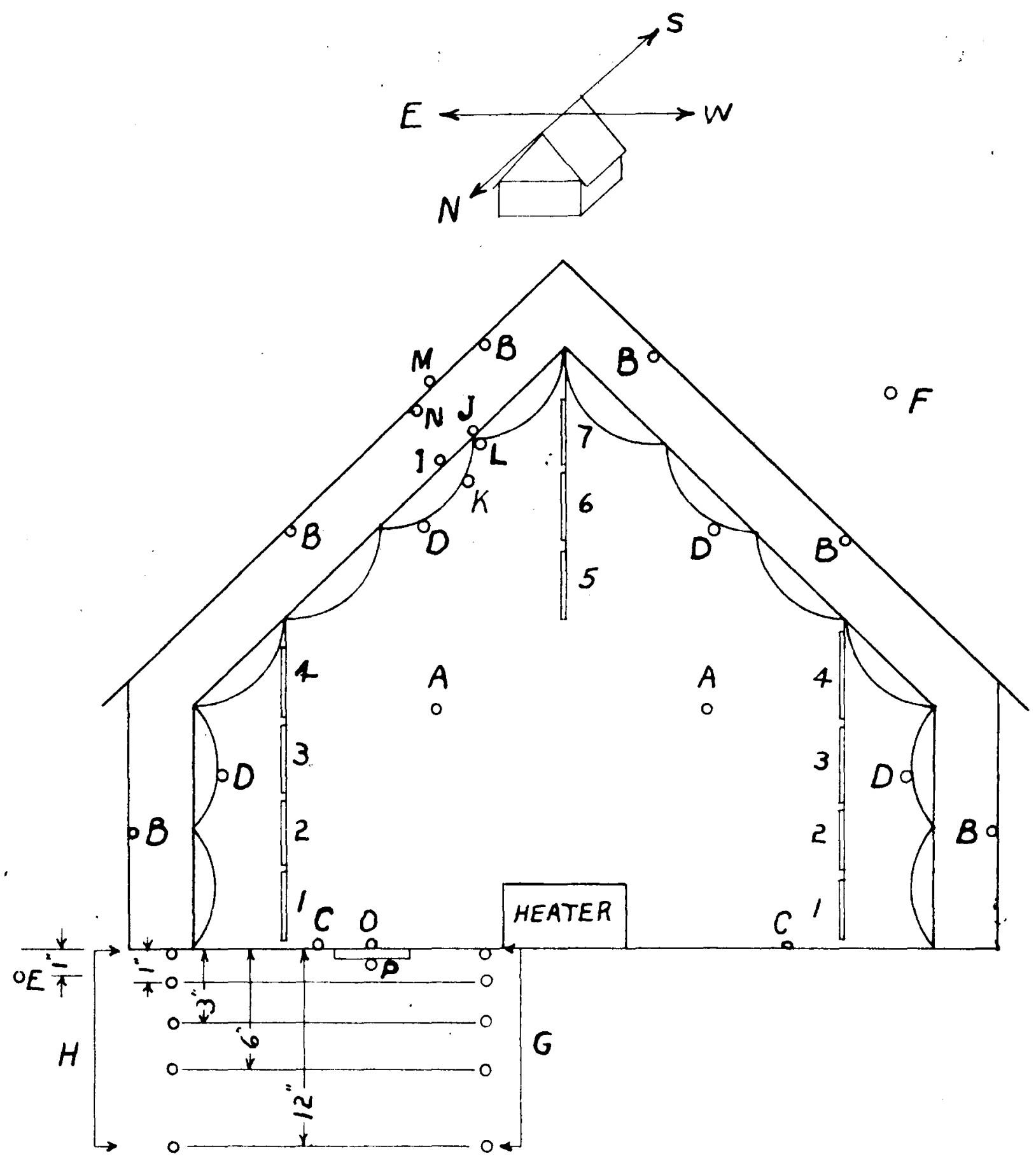

FIGURE 14 LOCATION OF TEMPERATURE MEASUREMENTS 
TENT TELPERATURE DATA - MINTER

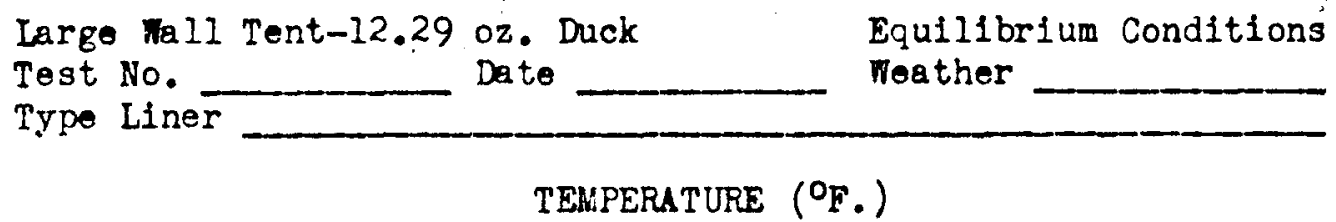

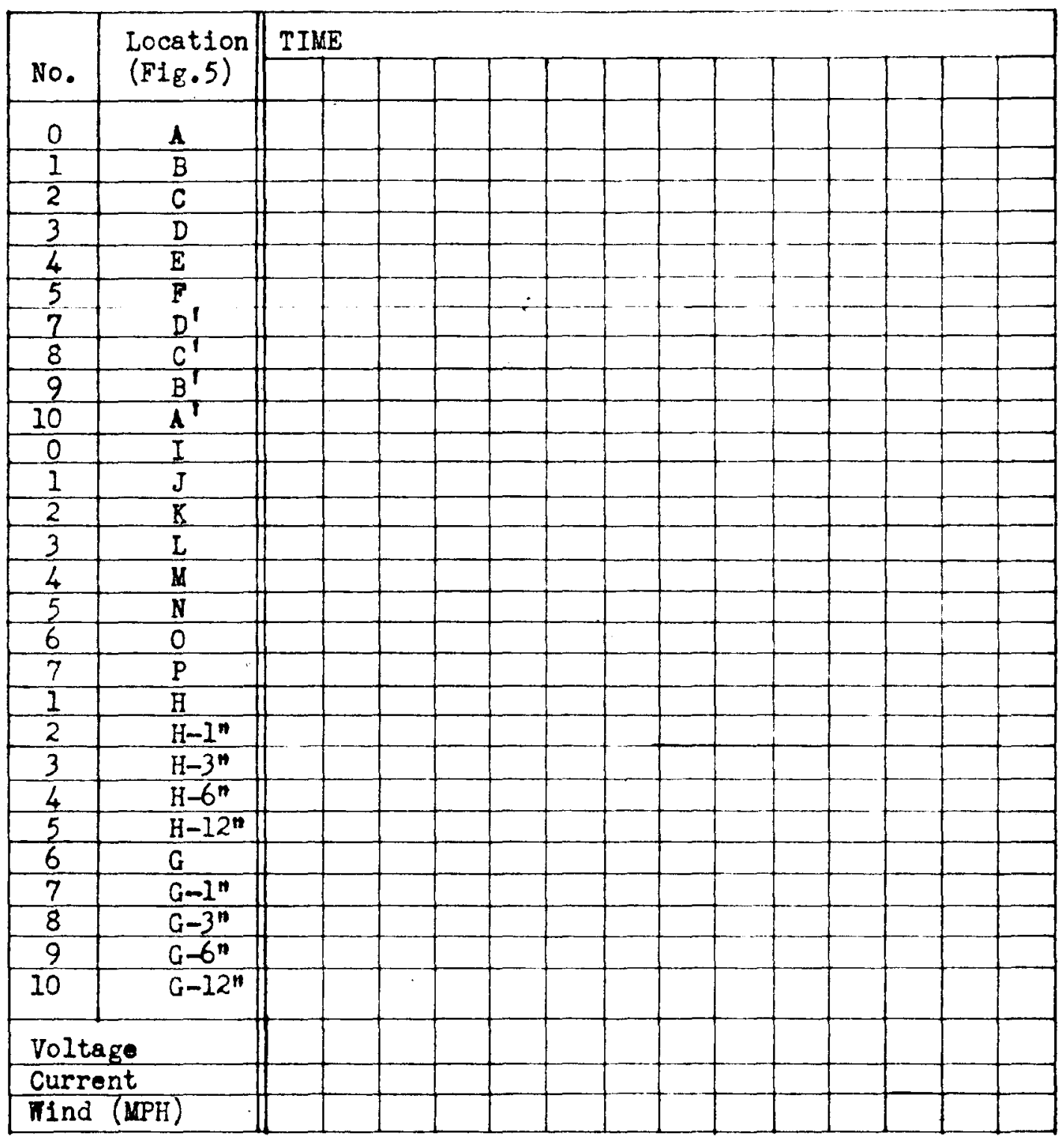

FIGURE 15 DATA SHEET FOR EQUILIBRIVIA CONDITIONS 


\section{TABLE VI}

\section{IESCRIPTIOR OF TEY EFATUPE VEASURERETTS}

A - Inside ar 3t it. beve floor, thermocouples in parallol, I In ench corner ft. from tbe walls.

B - Tent fabric, ins 10 , 10 thermocouplos in para 1101, 2 on ald - walls, 4 on deck, 2 on each ond.

C - around cloth, 2 tharwocouplos in parailel in alternate cornere of tont, 4 rt. erom the wail.

D - Incide 11ner, \& thermocouples in parallel, 2 on side walls, 2 on deck, 2 on each ond.

F - Outeide ground, 1 thormocouple, 3 ft. from northesest corner of test tent, 1 inch below sur race.

F - Outalde 1r, I thermccouple, I It, frow ground, it. from northwest cornor or test tent.

- Ground, s soparate thermocouples, 1 ft. from heater on the areface of ground, 1", 3", 6" and i2" below the aurfaos.

- Same ao only loested the conter of the oast slde of the tont.

I - Liner, outelde, I therwcoouple, not on seam, center of onat doek.

$J$ - Liner, outalod, 1 thermocouple, on neam, onter of east deck.

K - Liner, Inalae, 1 thermocouple, not on seam, conter of eat deok.

L - Liner, ine10e, I thermocouple, on seam, center of aat dock.

- Tent rabrie, outelde, 1 therrocouple, conter of east deck.

- Teat Iabric, Inalde, I thermocouple, center of sact oeck.

0 - Top of flow meter wite pine wood $8 / 16^{n}$ thick

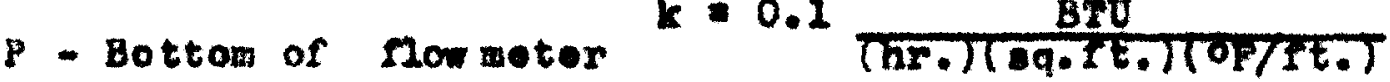

1, 2, 3, 4, 5, 6, 7 - Inald o ir the romotors, 1", 1', 21',

3f', 51, 6h', 81 above the floor levol, respectivaly.

Rote: All letters with primen are the same the rmocouple

arrengenent: In the roforence tent. 
TABLE VII SUESAY OF TSE EATUE CATA

LAPGE ALI. TEWT - $\$ O$ LINLR

\begin{tabular}{|c|c|c|c|c|c|c|c|c|c|c|c|c|}
\hline \multirow{2}{*}{$\begin{array}{l}\text { Tost } \\
\text { Ho. }\end{array}$} & \multirow{2}{*}{ Date } & \multirow[b]{2}{*}{ FIme } & \multirow[b]{2}{*}{ Find } & \multirow[b]{2}{*}{ 然enther } & \multirow{2}{*}{$\begin{array}{l}\text { Total } \\
\text { Beat } \\
\text { Input } \\
\text { aru }\end{array}$} & \multirow{2}{*}{$\begin{array}{l}\text { Eoat } \\
\text { Loas } \\
\text { Thru } \\
\text { Oround } \\
\text { Por Fou }\end{array}$} & \multirow{2}{*}{$\begin{array}{l}\text { geat } \\
\text { Loses } \\
\text { Thru } \\
\text { Fobrie } \\
\text { P }\end{array}$} & \multicolumn{2}{|c|}{$\begin{array}{l}\text { Test Tent } \\
\text { Tempere- } \\
\text { tures } \\
\text { op }\end{array}$} & \multicolumn{2}{|c|}{$\begin{array}{l}\text { Referenee } \\
\text { Tont } \\
\text { Teapera- } \\
\text { turese of }\end{array}$} & \multirow{2}{*}{$\begin{array}{l}\text { Ambiont } \\
\text { Alr } \\
\text { Texp. } \\
\text { of } \\
t\end{array}$} \\
\hline & & & & & & & & $t_{1 a}$ & $t_{1}$ & to & 4 & \\
\hline $\begin{array}{l}1 \\
2 \\
3 \\
4 \\
6 \\
6 \\
7 \\
8 \\
0 \\
10 \\
11 \\
12 \\
13\end{array}$ & $\begin{array}{l}1 / 27 \\
1 / 27 \\
1 / 27 \\
1 / 29 \\
1 / 28 \\
2 / 2 \\
2 / 8 \\
2 / 2 \\
2 / 2 \\
2 / 2 \\
2 / 8 \\
2 / 11 \\
2 / 11\end{array}$ & 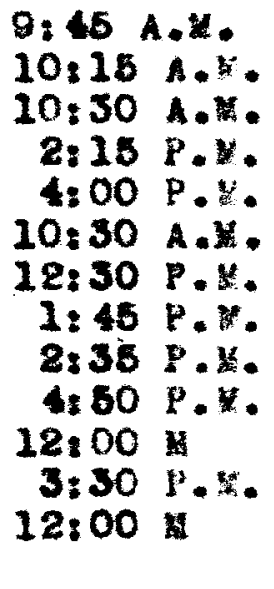 & $\begin{array}{c}\text { nogl. } \\
n \\
n \\
n \\
n \\
n \\
n \\
n\end{array}$ & $\begin{array}{c}\text { Pain } \\
n \\
\text { sunny } \\
* \\
n \\
\text { Yight } \\
\text { cloudy } \\
\text { Pain } \\
\text { Pight }\end{array}$ & $\begin{array}{c}12,200 \\
12,000 \\
\vdots \\
18,000 \\
22,500\end{array}$ & $\begin{array}{l}10 \% \\
" \\
" \\
" \\
" \\
" \\
" \\
" \\
"\end{array}$ & $\begin{array}{c}11,000 \\
10,800 \\
\vdots \\
\vdots \\
\vdots \\
16,200 \\
20,400\end{array}$ & $\begin{array}{l}47 \\
47 \\
54 \\
68 \\
18 \\
57 \\
78 \\
76 \\
78 \\
58 \\
10 \\
78 \\
68\end{array}$ & $\begin{array}{l}34 \\
33 \\
14 \\
53 \\
35 \\
48 \\
61 \\
60 \\
58 \\
43 \\
29 \\
64 \\
49\end{array}$ & $\begin{array}{l}27 \\
28 \\
34 \\
45 \\
26 \\
40 \\
51 \\
57 \\
62 \\
32 \\
21 \\
48 \\
38\end{array}$ & $\begin{array}{l}27 \\
30 \\
35 \\
49 \\
26 \\
10 \\
54 \\
61 \\
58 \\
32 \\
10 \\
48 \\
36\end{array}$ & $\begin{array}{l}9 \\
8 \\
12 \\
80 \\
20 \\
26 \\
28 \\
36 \\
34 \\
36 \\
18 \\
14 \\
35\end{array}$ \\
\hline
\end{tabular}

tia - mean a1s tomperature withir tent

$t_{P}$ - mean tort fabrle teapera ture

toa - ambient outeide alr terpersture 


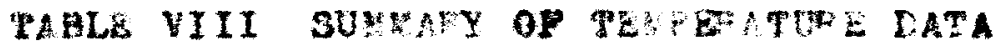

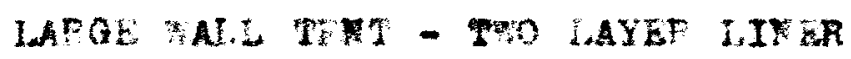

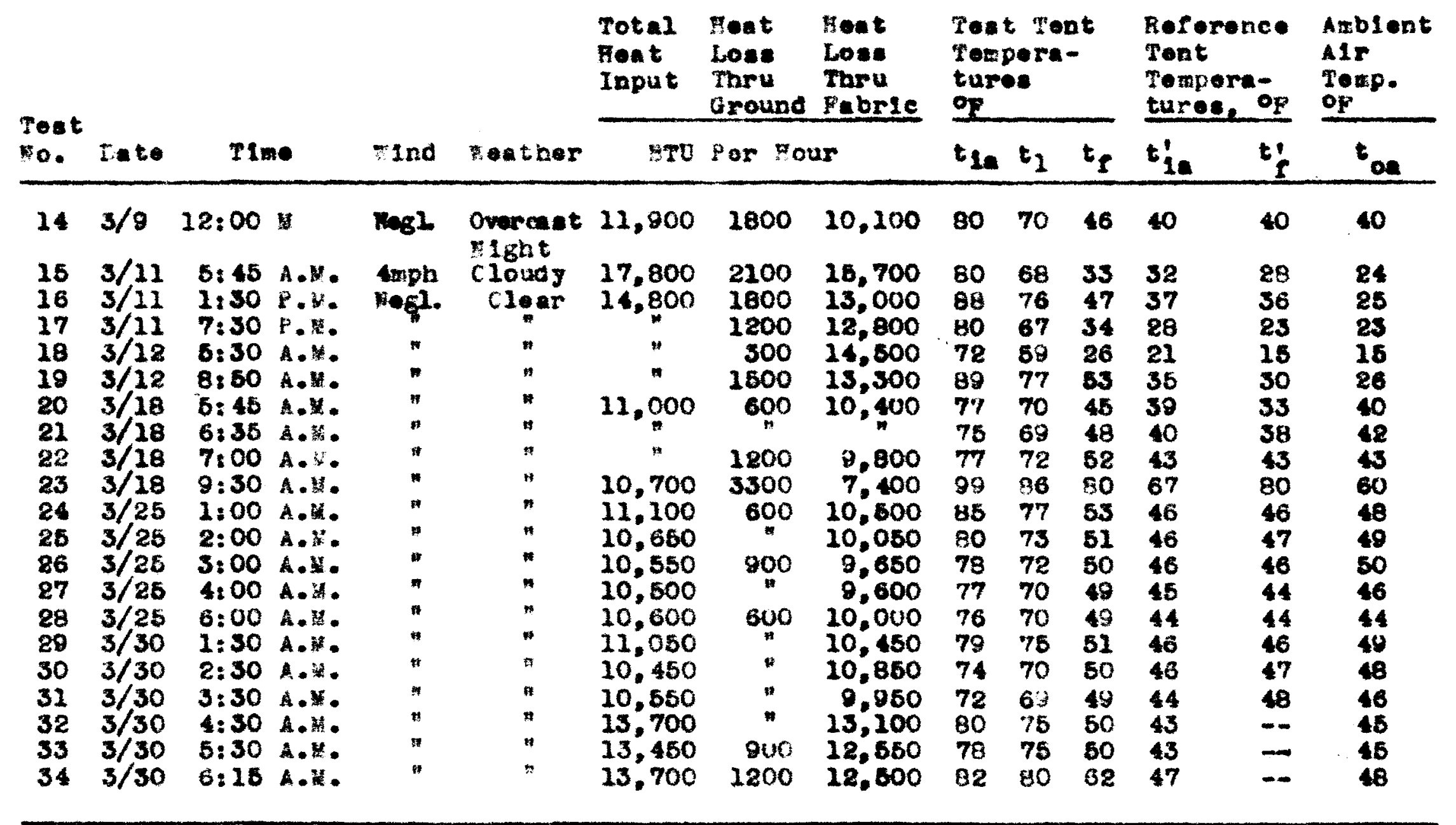


TABLE VIII (continued)

\begin{tabular}{|c|c|c|c|c|c|c|c|c|c|c|c|c|c|}
\hline \multirow{2}{*}{$\begin{array}{l}\text { Teat } \\
\text { no. }\end{array}$} & \multirow{2}{*}{ rate } & \multirow[b]{2}{*}{ 21me } & \multirow[b]{2}{*}{ ind } & \multirow[b]{2}{*}{ weather } & \multirow{2}{*}{$\frac{\begin{array}{l}\text { Total } \\
\text { Eoat } \\
\text { Input }\end{array}}{\text { BWU }}$} & $\begin{array}{l}\text { Foat } \\
\text { Loss } \\
\text { Phru } \\
\text { Oround }\end{array}$ & \multirow[t]{2}{*}{$\begin{array}{l}\text { Hoat } \\
\text { Lose } \\
\text { Taru } \\
\text { Fabric } \\
\end{array}$} & \multicolumn{3}{|c|}{$\begin{array}{l}\text { Tost Tont } \\
\text { Tempera- } \\
\text { tures } \\
\text { Op }\end{array}$} & \multicolumn{2}{|c|}{$\begin{array}{l}\text { Rererence } \\
\text { Tent } \\
\text { Terpera- } \\
\text { tures, op }\end{array}$} & \multirow{2}{*}{$\begin{array}{l}\text { Ambiont } \\
\text { Mir } \\
\text { romp. } \\
\text { op } \\
t_{\text {on }}\end{array}$} \\
\hline & & & & & & Por Eow & & $t_{\text {Ia }}$ & $t_{2}$ & $t_{t}$ & tie & ${ }^{t} !$ & \\
\hline 38 & $4 / 1$ & 12,00 & Negl. & overcast & 21,000 & 2100 & 9,900 & 86 & 84 & 80 & 5y & -- & 51 \\
\hline $\begin{array}{l}36 \\
37 \\
38 \\
39 \\
10\end{array}$ & $\begin{array}{l}4 / 3 \\
4 / 3 \\
4 / 3 \\
4 / 3 \\
4 / 3\end{array}$ & 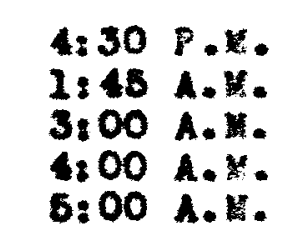 & : & cloar & 26.600 & $\begin{array}{l}900 \\
300 \\
600\end{array}$ & $\begin{array}{l}10,100 \\
10,700 \\
18,300 \\
16,000\end{array}$ & $\begin{array}{l}82 \\
65 \\
74 \\
78 \\
77\end{array}$ & $\begin{array}{l}80 \\
62 \\
72 \\
74 \\
74\end{array}$ & $\begin{array}{l}64 \\
38 \\
45 \\
42 \\
42\end{array}$ & $\begin{array}{l}56 \\
38 \\
37 \\
36 \\
37\end{array}$ & $\begin{array}{l}-5 \\
37 \\
36 \\
35 \\
35\end{array}$ & $\begin{array}{l}52 \\
38 \\
36 \\
34 \\
36\end{array}$ \\
\hline
\end{tabular}

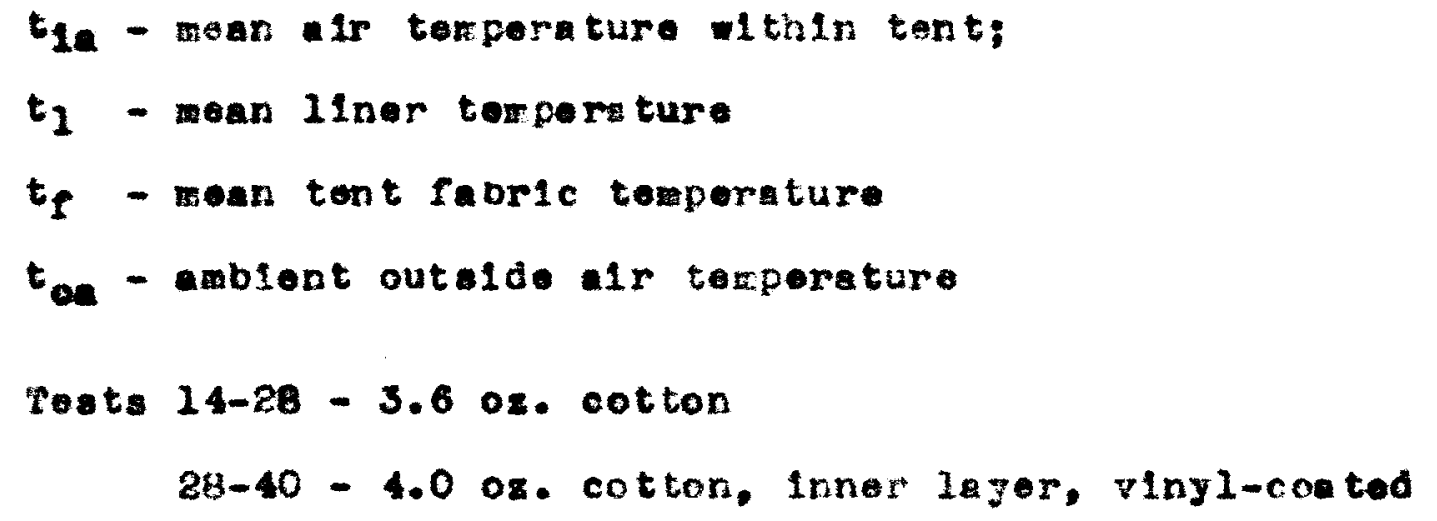


PSLE IX SE PAFY OF TH

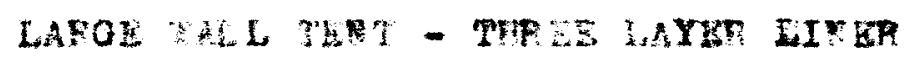

\begin{tabular}{|c|c|c|c|c|c|c|c|c|c|c|c|c|c|c|}
\hline \multirow{2}{*}{$\begin{array}{l}\text { Tost } \\
\text { No. }\end{array}$} & \multirow{2}{*}{ I to to } & \multirow{2}{*}{\multicolumn{2}{|c|}{$T 1=0$}} & \multirow[b]{2}{*}{ ind } & \multirow{2}{*}{ rea ther } & \multirow{2}{*}{$\begin{array}{l}\text { Potal } \\
\text { Foet } \\
\text { Input } \\
\text { Evu }\end{array}$} & \multirow{2}{*}{$\begin{array}{l}\text { Neat } \\
\text { Los: } \\
\text { Thru } \\
\text { Ground } \\
\text { Por got }\end{array}$} & \multirow[t]{2}{*}{$\begin{array}{l}\text { Font } \\
\text { Loes } \\
\text { thar } \\
\text { Fobric }\end{array}$} & \multicolumn{3}{|c|}{$\begin{array}{l}\text { Taat Tont } \\
\text { Taxpera- } \\
\text { turea } \\
\text { op }\end{array}$} & \multicolumn{2}{|c|}{$\begin{array}{l}\text { Roforence } \\
\text { Tent } \\
\text { Tenpera- } \\
\text { tures, op } \\
\end{array}$} & \multirow{2}{*}{$\begin{array}{l}\text { Ambient } \\
\text { A1r } \\
\text { Tenp. } \\
\text { op } \\
t_{\text {on }}\end{array}$} \\
\hline & & & & & & & & & $t_{1 a}$ & $t_{1}$ & $t_{r}$ & t. & $t$ & \\
\hline $\begin{array}{l}41 \\
42 \\
43\end{array}$ & $\begin{array}{l}2 / 21 \\
2 / 21 \\
3 / 1\end{array}$ & $\begin{array}{r}1: 06 \\
3: 00 \\
11: 80\end{array}$ & $\begin{array}{l}\text { A.M. } \\
\text { P.X. } \\
\text { A. B. }\end{array}$ & $\begin{array}{c}3.5 \mathrm{mph} \\
\mathrm{k} \cdot \mathrm{fof}\end{array}$ & $\begin{array}{l}\text { Cloudy } \\
\text { Snov } \\
\text { Cloudy } \\
\text { rin }\end{array}$ & $\begin{array}{r}15,500 \\
14,400 \\
8,650\end{array}$ & $\begin{array}{l}1500 \\
2100\end{array}$ & $\begin{array}{r}14,00 \\
13,40 \\
6,55\end{array}$ & $\begin{array}{l}86 \\
82 \\
82\end{array}$ & $\begin{array}{l}76 \\
72 \\
77\end{array}$ & $\begin{array}{l}38 \\
36 \\
86\end{array}$ & $\begin{array}{l}31 \\
31 \\
58\end{array}$ & $\begin{array}{l}25 \\
26 \\
70\end{array}$ & $\begin{array}{l}26 \\
84 \\
46\end{array}$ \\
\hline $\begin{array}{l}44 \\
45 \\
46 \\
47 \\
48 \\
40 \\
50 \\
51 \\
52 \\
53\end{array}$ & $\begin{array}{l}3 / 1 \\
3 / 1 \\
3 / 2 \\
3 / 3 \\
3 / 3 \\
3 / 3 \\
3 / 3 \\
3 / 5 \\
3 / 5 \\
3 / 7\end{array}$ & $\begin{aligned} & 1: 30 \\
& 10: 30 \\
& 12: 00 \\
& 10: 30 \\
& 1: 20 \\
& 4: 30 \\
& 0: 30 \\
& 12: 00 \\
& 9: 00 \\
& 12: 25\end{aligned}$ & 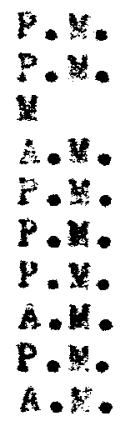 & $\begin{array}{c}" \\
" \\
2.8 \mathrm{mph} \\
" \\
"\end{array}$ & $\begin{array}{c}n \\
\text { Overeast } \\
n \\
\text { Clear } \\
m \\
m\end{array}$ & 11, 800 & $\begin{array}{r}1200 \\
1800 \\
1800 \\
1800 \\
600 \\
400 \\
1800 \\
1200\end{array}$ & $\begin{array}{r}7.460 \\
7.160 \\
7.450 \\
7.150 \\
8.550 \\
7.760 \\
7.450 \\
6.560 \\
7.160 \\
10.800\end{array}$ & $\begin{array}{l}76 \\
76 \\
75 \\
73 \\
84 \\
72 \\
70 \\
80 \\
70 \\
73\end{array}$ & $\begin{array}{l}74 \\
70 \\
70 \\
67 \\
78 \\
66 \\
65 \\
74 \\
68 \\
66\end{array}$ & $\begin{array}{l}56 \\
47 \\
46 \\
73 \\
84 \\
72 \\
70 \\
58 \\
40 \\
34\end{array}$ & $\begin{array}{l}53 \\
44 \\
43 \\
44 \\
56 \\
46 \\
34 \\
64 \\
38 \\
32\end{array}$ & $\begin{array}{l}63 \\
42 \\
41 \\
47 \\
58 \\
42 \\
36 \\
67 \\
34 \\
24\end{array}$ & $\begin{array}{l}40 \\
42 \\
41 \\
10 \\
46 \\
42 \\
36 \\
42 \\
37 \\
31\end{array}$ \\
\hline
\end{tabular}

ta - mean alr tenperature ithin tent

$t_{1}$ - men liner tenporature

$t_{f}$ - mean tont fabric temporature

$t_{\text {oa }}$ - molont olitaloe ir temporature 
Ground 108808 , values arve 10 per cent with low heat inputa and loser values as the errund becare wrwer with long heatIrs perind or wien the outsioe sround ter sersture increased. FIgure 16 ahow the change in ground temporature with timo.

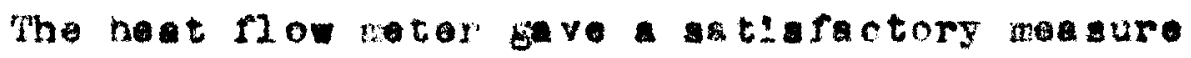
of the dround losea; however. It wa posalole to check the

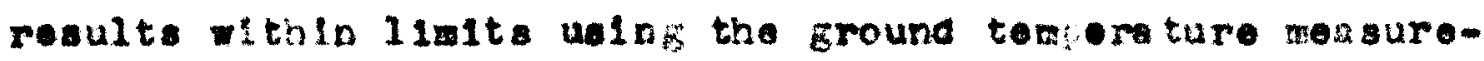
ments. uring a perice of 14.6 hours, tho heat contert of the ground down to the 12 Inch. Lovel wa increased by 18.400 BTU, and in this same perlod the total hat oupplied to tho tent wa 126,000 ATU, Inalcating 14.7 per cont of the total neat to the tent wo los to the ground. over the same per100 exrouna 108 of 16.2 per cent wa calculatod from mosurements wi th the heat flow roter.

In these rune in wich the flog metor was used. the heat $10 \mathrm{~s}$ to the eround was calculstod. In other teata the ground los wa asured to be 10 per cant of the total hest 10se. These loses wer subtractec fron the total heat input to the tort to obtain the neat tranoforrod through the faric.

Velng the technioues or caloulating the total heat Input, ground 20as, and malstion erfects a proviovity aeseribed, the verall coefflelents of hat eranafor from the alr inato the tent to the outaio alr wero cotalnad for all test runs. Arorag values of these ooefficients for the different tent asarblles aro shom in table $y$. 


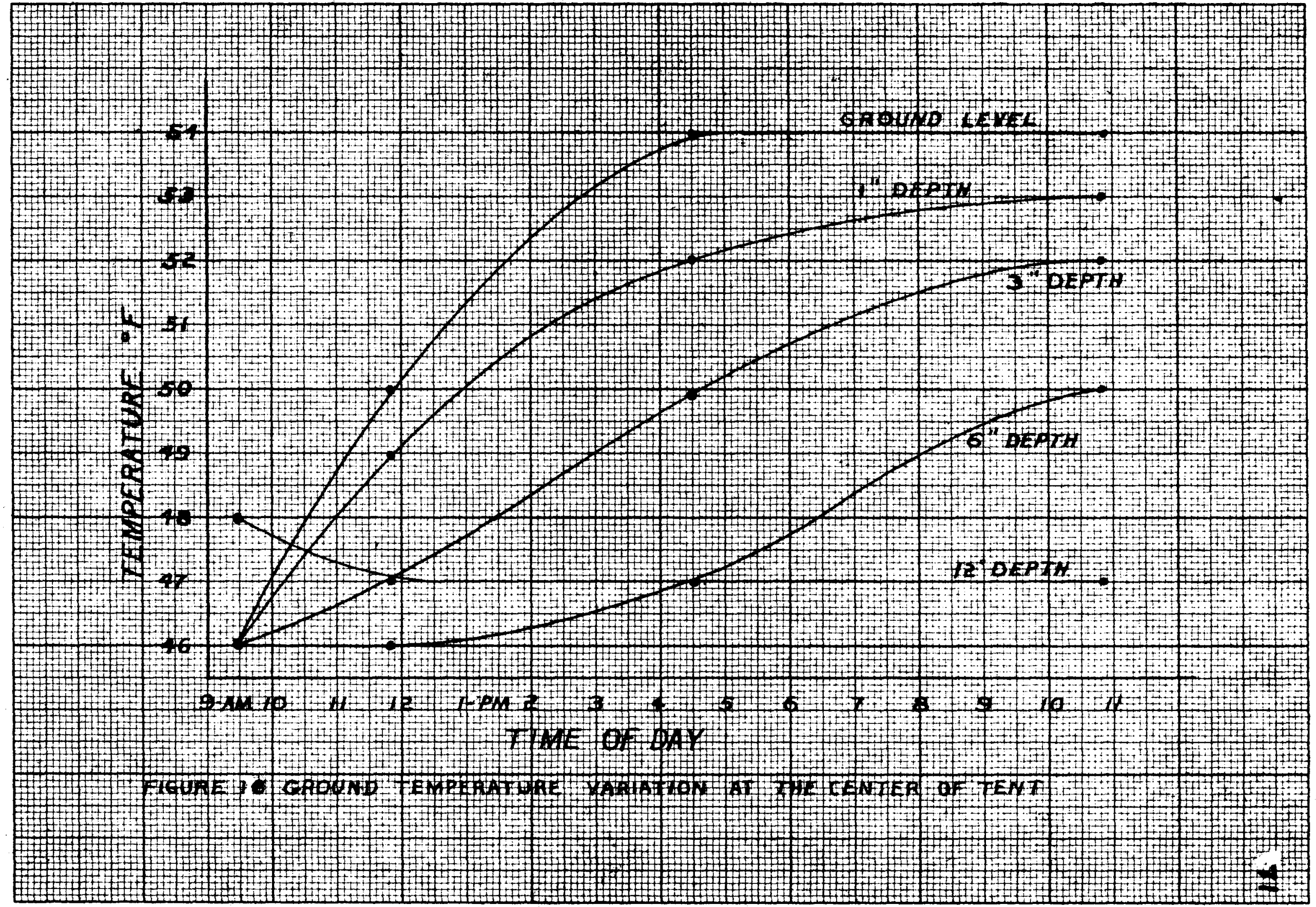


PABLE $X$

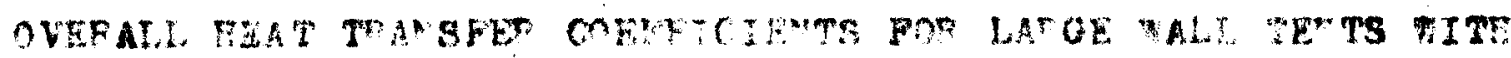
MUTILAYGT LINERS

Assembly

overall Coefficiont $\mathrm{BrU} /(\mathrm{nr} \cdot)($ oo.ft. $)(\mathrm{OF})$

Large nll Tont, No Linor

0.92

Large tall Tont, 2 Layare, 3.6 oz. Bulloon Cloth Liner 0.46

Large hall tent, 2 Leyere 4 oz. Cotton, VInylcou tod, Liner

0.54

Large : 11 Tent, 3 Layers, 4 oz. Cotton, Liner 0.41

* Yind Velocity Megligible

In the tests of the Inter of 1946-47 ooefficionts for the lare wall ten to witi single layor liners were obtolrod as atom in the followine table(6):

\section{TABEE XI}

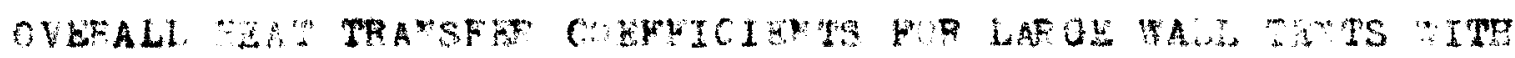
STMGI LAYR LINERS

Assurbly

ovorall coofficiont*
BTO/(ar.)(sa.ft.)(OF)

Lerge hell rent, No Linor

1.26

Large mell Fent, 4 os. White Cotton, Liner

0.58

Large all tont, 8 ox. Cotton, 0.1.,7, Liner

0.88

Large sell font, in. Thlcknose of Fiberglas

rine loer betweon ox. Cotton, liner

0.30

* Find velocitg Negligible 
An Inspection of the values in those teblos, rable $y$ and lable $Y I$, reven lo lower value of the coofflcient for the tent witi no linor for the intor of 1947-46 than that obtained In 2046-47. This lesser value was attributed to the Lower alr pelocitios, esentielig zero, oncounterect in working with the tert the liner ourlng the Inter of 1947-48. since the tont with no linor operos upon only tao fir flima for resis tonce to hoat slow, the valuo of tho orerali cooffickent is so:lously influercod by aligt changes in oxtornal conditions. Noweror, In tho case of tenta with linors slat chenges in external contitiona aro laso noticeable in tho value of the orerall coeffictont.

A corslderition of the conductarices of atr spaces and incivioual coofficiorts as roportod for structuraliy stable materials, auch as, concrote, retal, jiass, etc. shows the ultimeto insula tlon that can be expected of the fabric syster. In thich the resistance of forec by the fabric is rog1181010.

For the type of arface siallar to cotton liner an inside eurrace coefflciont of 1.85 to obtained. Since the wind velocity is rogligible in wout of these rune, an outaloe cooflictent of 2.0 should apply. for the conductances of the al s secea at a mean terperature of $40^{\circ} \mathrm{F}$. a value of 1.1 can be used. (Those values agreo with those reported in the kmerican soclety of Venting and vent1leting angineers oulde. $)^{(7)}$ 
If the tart atructure wero tabie and the a apaces wero equiviont to at121 ar. the ralues of the over- 11 cosflelents a calculeted for fable YII woula be obtaned.

TAPI: XII

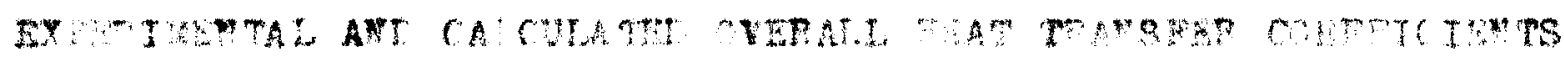

Asembly

overall coefpletenta

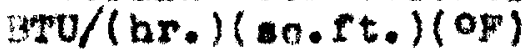

ispomirentel calculated

Laro vall Tort, Mo Liner

0.92

0.96

Larbe 11 tort, Single Layer Liner

0.68

0.62

Large wall Tont, Loublo Layar Liner

0.45

0.35

Larte rall Tont, shree Lay or Lnor

0.4

0.27

since a tont la not etructura $11 y$ table (as contrastod wth concrote wil) but moves ith even tho slightost ar movement, true ot111 air apaces would ardly be expected. In sodition, there ia undoubtediy considerablo a ir infiltration through seawe, growet holed, doop openinge, te., and In the case of 11nera of more then ono layor, alr gaces are destroyed at the lines of atitching holdins the two fobrio layere together. In meng pleces to liners woula not hang in such way that all posalblo separation of the fabric layers was rolized. MI the so consloerationa wuld tend to In- roase the experlagntal value of the coeflicienta ubove the calcula ted val ue s. 
Fron tho comparisons of foble XII it appese that the doublo lay or liner is the rost offlcient la reducing the boat losses for the welgt and cost involved. The addition of insulation realized with th to three-layer liner is not auriciont to fustify the adoltional wolght and cost. hlthough the Iner incorperetine the flberglas (proviouly exmineol gave a coefficient of $0.3 \%$, wherses the threo-layer iner gave value of 0.41 , Ita coat, welight, no bulk did

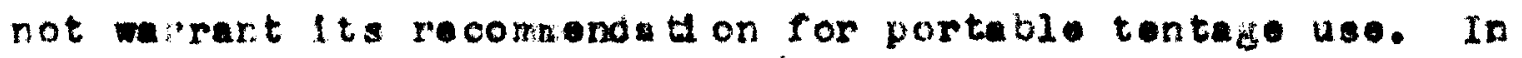
addition, it is folt that som changes in the fabricating tochnique for the multi-layer 11ners to give maxlatim ut121zation of the posalblo alr epaces would incroase thelr value for tontage inaulation.

MIO" RUYLITY WITIE THL THN

In most of the runs the partal preseure difforence of the water vapor in the inside andoutside ir was too anall for censidertion of difrusion or condenasion. To atudy tio offects of algeifleant vapor prosoure difference between the ine1de and outside alr, several runs were wade wh110 water we belng bolled within the tonte.

ino 110-rolt hesters wore connected in sorios and parallolod witi: tho hoatine units. One ourt contalnurs woro placed on these sutere and wator wan bolled continuously during the equilibrius runs. Therefore, a portion of the 
total eloctrical power suppliod to tho tent was oxpended in vaporizing tho watior. This vafor, at approximelely $2180 \mathrm{~F}$, , tranoforrad anolble heat to the alr vapor mixture.

A calculation of $t$ overall not transer coeficlente for these runs in the ranner provlousiy described gave htigh velues, $0.00(0.54$ with no ovaporation) for the two-layer yingl-coatod 11ror and 0.50 ( 0.45 wth no ovaporation) for the two lar or 3.6 or. cotton liner. Vowovor, when the heat supplied for the evaporation of the water wa deductod from the total he at input and coerficionts calculated on this basels, obnormally lou values were obtalnod incleating that sere deat was galnod b: concersation of the molsture. Ey ualne the two alf forert voluos of the coefficients to calculate the heat obtalned in the condenation wh the value of the latont hoat, the anount of condensation was calculated. Po: a partial prossuro difforonce of $8.6 \mathrm{~mm} y$, It was found by the calculation procodure described bove the 50 per cort of the ovaporated water conderised when the 3.6 oz. cotton linor was usod, although no conodenasion was observed on the surface of the liner expoed to the interior of the tent. Therafro, it was conoluded that the condenation took place on the cuter fabric lajers.

Then the vinyl-costed liner wa used with partial pressure difference of $14.6 \mathrm{~mm} F, 42$ por cont of the -vaporated water condonsod. In tins caso, cordersation was observed on the liner surfece to the inoldo of the tent, indicating that litulo wer condensed in the outer fabric layers. 
COrCLUSIOng 
Frow the resulte of this tudy 11ners were found to bo en effective means of roducing beat $10 \mathrm{se}$ from tents. Tho conjarative valued of the hoat los a coefletents gave good indicatione of the value of liner-tent combinatione over the range of wind volocition oncounterec in the so tests. A tent wh no liner wa found to have oofficlent of heat 108 of $0.92 \mathrm{BTU} /(\mathrm{br}).(\mathrm{so} . \mathrm{ft}).(\mathrm{Op})$, whereas the cofflelents for the elnele layor liner, dowble layer liner and three layer liner were found to be $0.58,0.46$, and $0.41 \mathrm{ard} /(\mathrm{hr}$. (so.ft.) $\left({ }^{\circ} \mathrm{p}\right)$, reopectively.

All of the experimed 1 coefficients for the linor-tent aserblles wero found to be higher than calculated coerricionte for the ame asenblien. Since all cal-

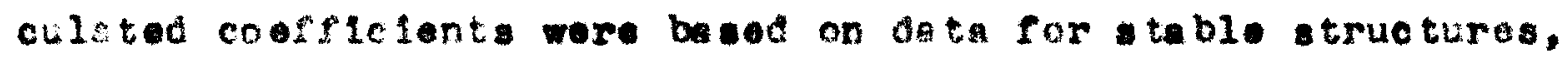
the reason for this difforonce is roedily acen. Alf infiltretion wa neglocted; true st111 alr spaces would hardly be expected ant ir spece woro not alway uniform. All of these conslderations would tono to increase the exporiuortal values of the coefrielonta.

Pros the reaulto obtal nod, mult1-layer linere were found to be oufficiently of sective for roducing heat loses from ventage to juetify their use. Although the three layer liner gave an average overall coe Mclent slighty below that for tho two layer liner, the double layer liner was coneldered the wost satiafactory from the viopolnt of hest losa, bulk, wol hit ane cost. 
LITHRTHE CITH 
(1) Bernos, ¿., Barvin, P.L., M1111me, 0.2, anc oorherd, E.F., "Improved realgr of lents and Tontege veterials July, 2946 - June, 1947" inlveralty of Loulavilio Inatitute of Industrial Posearch, Loviovillo, $\mathrm{ky}, 1947$ pp. $22-86$

(2) Micholla, P., "Yeauring oat Transission in valldig

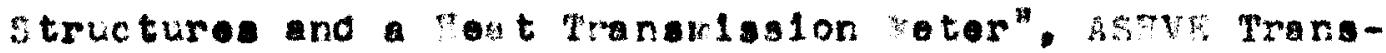
actions, 1924, vo1. 30, pp. 366-369

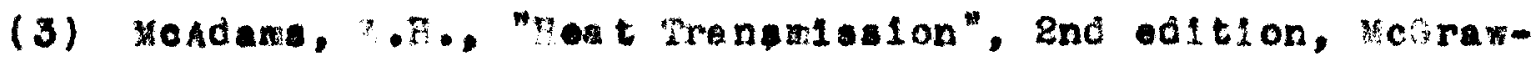
D111 13.k Comany, Now York, 2942 pp. 394

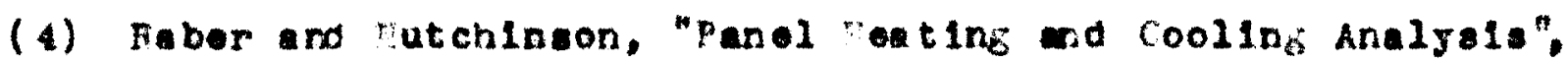
lst edtion, vol. I, John llog and Son, Yom York, 147 pp. $61-62$

(s) Sarnes, ..., op. c1t., p. 33

(6) Ibld., p. 43

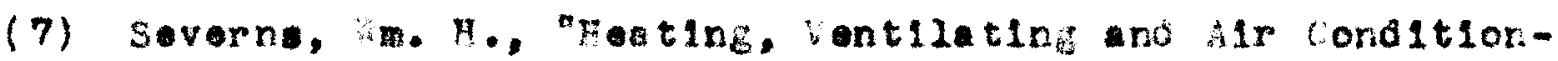

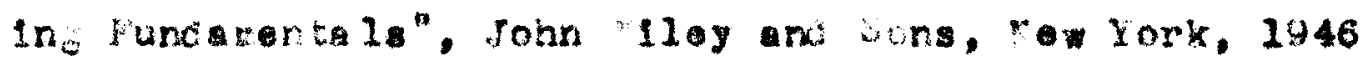
pp. $47-48$ 
A $=$ THIX 


\section{LIS: TY TROLS}

Mamo

\section{Aron}

Coofficiort of tout Transfor, Convection

coerficlont of tont Transfor, Convection, overall

coefriclent of "out Transfor, ivorall

coofficiont of Dont Transer, Fadiation

coofflesent of taosit Travarer, Radiation, ovorall

istance

Emissivity Factor, Radiation

Heat flox, cuntey

Foet Flow, Rato

"eat Flow, Rate, Lost by Convection

vert k10w, Rate, loot by wat Tent

Yoot Flow, Fiate, Pocolvod by Radiation

Hot low, nate, uppliod by nontor

Heat flow, pato, Total vout Lost

Spocisic Toat

Temporature, Arerago, Inolo alr

Torporature, Avorace, Dutajo Alr

Ton fereture, ifferanco

Forperaturo, fabrle

Tonforeture, Fabic, Abolute symbole

A

sn.ft.

$b_{e} \operatorname{erts} /\left(a r_{0}\right)\left(\right.$ eq.et. $\left._{\bullet}\right)\left(O_{p}\right)$

$v_{c}$

n

v

$n$

$h_{\mathbf{r}}$

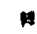

$v_{p}$

x

ft.

.

$Q$

BTV

$q$

RTU/hr.

90

$a_{t}$

$q_{r}$

i.

$a_{h}$

97

ep

arv $/(2 b).\left(\mathrm{OP}^{\mathrm{F}}\right)$

toa

op

ton

$*$

$\Delta t$

n

$t_{f}$

$n$

$T_{r}$

${ }^{\circ} \mathrm{R}$ 
LIS: of S:3BOLS (oontinuod)

xime

Symbol.

Dnits

-

Teaperature, Ground, Abeolute

$\mathrm{T}_{\mathrm{g}}$

OR

Tenperature, Jean Fadiat

$t_{m r}$

$O_{F}$

Ton perature, surface, Absolute

T.

of

Thermal Conouct! 1 ty

k

BTU $/\left(h r_{0}\right)($ sa.ft. $)(\mathrm{OH} / \mathrm{st})$

Nolght

*

2b.

Vote: All prinos (1) rofor to roforence tont. 


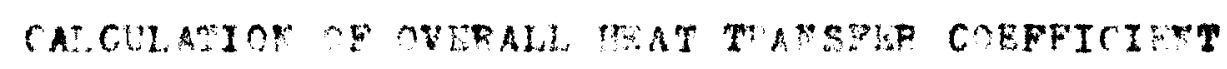

Ualng data for run nurber 50 , the total hoat input was $8,350 \mathrm{BrU} / \mathrm{hr}$. The he at $10 \mathrm{~s}$ to the eround wa $900 \mathrm{gro} / \mathrm{hr}$. , a calculatod uelng the heat flow reter. Fror equation (7),

$Q_{h}=U_{n}\left(t_{1 a}-t_{1 a}^{\prime}\right)$

whore $a_{h}=(8,360-900)-7,450-6 / \mathrm{hr}$.

$A=000 \mathrm{st} .^{2}$

$t_{1 a}=700 \mathrm{p}$.

$t_{1 a}^{\prime}=39^{\circ} \mathrm{H}$

- value for of $0.40 \mathrm{kTV} /(\mathrm{mr}).(\mathrm{se} . \mathrm{ft}).(\mathrm{OF})$ is obtalrod. 


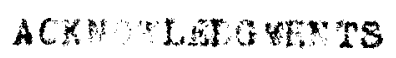


Ith 1. reserch wa made possiblo through a rellowahlp grant from

The University of Loulov111e Inatitute of Industrlal Fosoarch

as a portion of contracted rosearch w: th

The Louss 1110 In and stove Company

and

The off:ce of the cuartermator Goneral

W11tany lanning Liviaton

Rosearch ard iovelopmert Branch 
VIYA 
The author O: this thos 1s, Fobort Eeaman I uggan, was born Apr11 22, 1926, In Lorver, Colorado, the son of

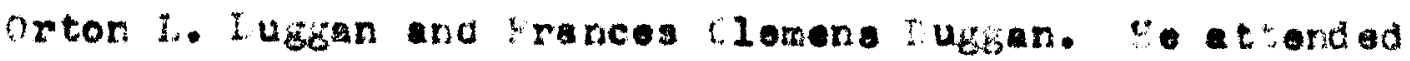
grade chool in lallas, texas and Knoxvillo, ionnesses ano

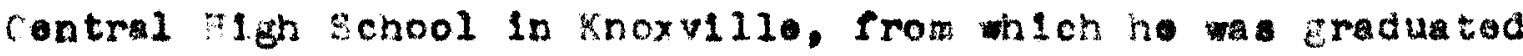

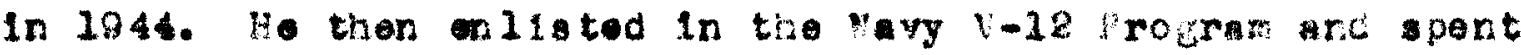

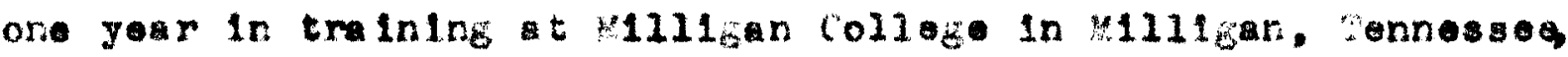
and one year at Speod Sclontific chool in Louls vilio, Kontucky.

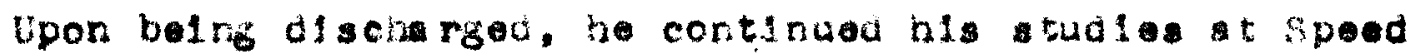
selentific school, frov. Which be roculvod the degroo of Dacholor of Hochanical kngtnoorine, in september, 1947. Subsecuent to his graduation, ho onrolled in tho gradute school of the Universtty of Loulovilio and rocelved hls vater of tochenlenl inglneerlng dogroe in Juno, 1949. "18 zaster's work incluced followship in the Institute of Incustrlal rosearch, Univers!ty of Loulgul110, whore he morked

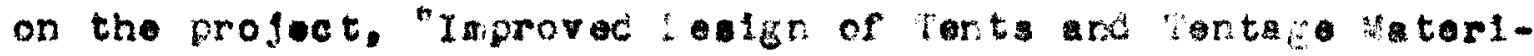

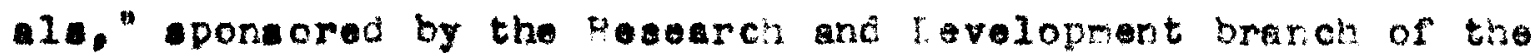

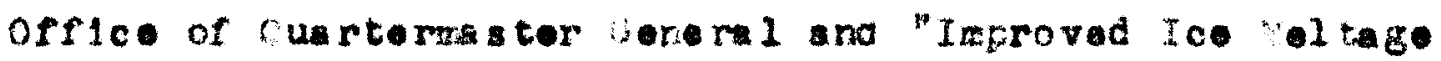
Characterlstics of the frogress fce Eox," sponerod by the Loulav111. In and Stove company. 